\title{
Industrialization and Democracy
}

\author{
Sam van Noort*
}

December 5, 2021

\begin{abstract}
I provide a new theory of the relationship between economic development and democracy. I argue that a large share of employment in manufacturing (i.e., industrialization) makes mass mobilization both more likely to occur and more costly to suppress. This increases the power of the masses relative to autocratic elites, making democracy more likely. Novel manufacturing employment data for 145 countries over 170 years (18452015) supports this hypothesis. First, all highly developed countries in the West and East Asia democratized when approximately $25 \%$ of their workforce was employed in manufacturing, and virtually no other country has ever reached this level without eventually becoming a well-functioning democracy. Second, industrialization is strongly correlated with democracy, even after accounting for two-way fixed effects and other economic determinants of democracy (e.g., income and inequality). Last, unlike with other economic determinants the effect occurs on both transitions and consolidations, and is equally large after WWII.
\end{abstract}

Keywords: Industrialization, Democracy, Modernization Theory

Words in text: 9,941 (excl. online Appendix and abstract)

${ }^{*} \mathrm{PhD}$ candidate at the University of Cambridge and fellow at the Niehaus Center for Globalization and Governance of Princeton University. I am grateful to Toke Aidt, Fernando Bizarro, Dawn Brancati, Brian Burgoon, Ha-Joon Chang, Richard Clark, Andrew Eggers, Grzegorz Ekiert, Patrick Emmenegger, Tanushree Goyal, Hanna Kleider, Steven Levitsky, Michael Miller, Peter Rosendorff, David Rueda, David Samuels, Milan Svolik, Jan Vogler, and seminar participants at Oxford University, Princeton University, Harvard University, Yale University, University College London, the Historical Political Economy Working Group, and the Annual Meetings of the American, Midwest, and European Political Science Associations, for helpful comments and suggestions. Financial support from the Vice-Chancellor's Award at the University of Cambridge and the Fox International Fellowship at Yale University is gratefully acknowledged. 


\section{Introduction}

In 1988, South Korea transitioned from a military dictatorship to a democracy. Many scholars agree that this democratic transition was, in no small part, due to the process of rapid economic development in South Korea between 1963 and 1988 (e.g., Ahn (1997), Armstrong (2007), Huntington (1991), and Kim (2000)). Yet, when one focuses on the common economic variables used in the democratization literature-i.e., income (Boix, 2011; Epstein et al., 2006, Miller, 2012, Treisman, 2015), income equality (Boix, 2003; Acemoglu and Robinson, 2006), education (Glaeser, Ponzetto and Shleifer, 2007; Dahlum and Wig, 2019, 2021), and urbanization (Beissinger, Forthcoming, Cirone, 2021; Fresh, 2022) - it seems difficult to explain why South Korea democratized in 1988 at all. For example, of the countries coded as "not free" by Freedom House in 2015, 35.7\% had higher levels of income, $26.1 \%$ had higher levels of Gini equality, $11.8 \%$ had more years of education, and $42.3 \%$ had a higher level of urbanization than did South Korea in 1988. As I demonstrate in this paper, all the other currently highly developed countries in the West and East Asia also democratized on levels of income, equality, education, and urbanization that are low even by the standard of many of today's most autocratic developing countries.

I argue that this discrepancy occurs because a shift towards a large share of employment in manufacturing (i.e., industrialization) is an important overlooked channel through which economic development can lead to democracy. I provide novel microfoundations for this hypothesis and use novel long-run manufacturing employment data to show that industrialization is robustly related to both transitions to and consolidations of democracy. The South Korean case illustrates the strength of this hypothesis. In 1988, $24.2 \%$ of the South Korean workforce was employed in manufacturing. No country (including China and the USSR) has ever reached this level of industrialization without eventually becoming a stable democracy.

The key causal mechanism that I highlight is how a large share of employment in manufacturing makes mass political mobilization both more likely to occur and more costly to suppress. Factory production requires large groups of workers to function together in highly 
specialized roles. Doing so efficiently requires instilling manufacturing workers with a wide range of organizational capabilities that foster cooperation on a large and impersonal basis (e.g., negotiating and working together with strangers, addressing disagreements, accepting authority of leaders, and disciplining free riders). Many of these organizational capabilities are transferable to mass organization in general, and, therefore, unintentionally increase manufacturing workers' capacity to mobilize politically. Industrialization further increases the mobilization capacity of manufacturing workers because efficient manufacturing production typically requires the agglomeration of large groups of manufacturing workers in urban areas, which lowers information and coordination constraints, and thereby reduces barriers to collective action.

Industrialization simultaneously increases the cost of political repression for autocratic elites. The significantly greater forward and backward linkages in manufacturing make that economies that rely heavily on manufacturing are much more strongly disrupted by political instability than countries that do not (e.g., strikes in one industry directly affect many other industries that supply or demand goods to/from the disrupted industry). Furthermore, repressing mass protests in highly industrialized countries is particularly expensive because revolts tend to be more frequent, larger, better coordinated, and closer to urban centers of power (Butcher and Svensson, 2016; Dahlum, Knutsen and Wig, 2019; Tilly, 1978). Once autocratic elites perceive the cost of redistribution under democracy to be lower than the cost of continual political repression they stop resisting and democracy becomes a stable political equilibrium (Boix, 2003, Rosendorff, 2001).

To test this theory I assemble a new dataset on manufacturing employment and democracy for a sample of 145 countries over 170 years (1845-2015). I generate this data by scraping the census data incorporated in Mitchell (2013), and combining this with manufacturing employment data from both the United Nations Industrial Development Organization (UNIDO) and the Groningen Growth and Development Centre (GGDC).

Using this novel data, I report four key findings. 
First, industrialization is clearly empirically distinct from the other more widely studied economic determinants of democracy. While Lipset (1959) famously argued that the factors of industrialization, urbanization, wealth, equality, and education are so closely related to each other that they can better be considered as attributes of the same underlying factor, I show that this is only because all highly developed countries eventually tend to reach high levels of industrialization, urbanization, income, equality, and education. When one looks within countries over time, however, one sees that all currently highly developed countries in the West and East Asia have reached high levels of manufacturing employment several decades before they reached high levels of income, equality, education, and urbanization (Osamu and Shaw-Taylor, Forthcoming). In contrast to Lipset (1959), changes in industrialization within countries over time only share $18.1 \%, 4.5 \%, 27.4 \%$, and $11.1 \%$ of their variance with changes in income, equality, education, and urbanization at the same point in time.

Second, I show that the timing of democratization in the currently most highly developed countries in the West and East Asia is consistent with the hypothesis that industrialization tends to induce democracy. Virtually all of today's highly developed countries democratized shortly after reaching high shares of employment in manufacturing, and all democratized on levels of industrialization virtually unprecedented by any undemocratic country today or in the past. Again highlighting the importance of studying the effect of industrialization as distinct from other standard economic variables, I also demonstrate that all of today's highly developed countries democratized on levels of income, equality, education, and urbanization that are low even by the standard of many of today's autocratic developing countries.

Third, I show that industrialization is strongly positively correlated with democracy. Crucially, I find that many of the existing empirical challenges to the hypothesis that economic development tends to induce democracy disappear when one focuses on industrialization rather than on income, equality, education, or urbanization. In particular, I find that the effect remains robust to country and time fixed effects (Acemoglu et al., 2005, 2008), oc- 
curs on both transitions to and consolidations of democracy Houle, 2009; Przeworski and Limongi, 1997), is equally present in more recent time periods (Boix and Stokes, 2003), and occurs in both the long and the short term (Treisman, 2015). Using standardized regression coefficients I find that the effect of industrialization on democracy is at least several times larger than the effect of GDP per capita, Gini inequality, average years of education, urbanization, as well as many other standard determinants of democracy (e.g., oil rents) \ Using the method of Oster (2019), I find that assigning the entire association between industrialization and democracy to endogeneity requires the effect of unobserved confounders to be approximately three times stronger than the strongest observed co-determinants of industrialization and democracy highlighted in the existing literature.

Last, I find that industrialization strongly increases mass political protests dominated by industrial workers, and that such protests are particularly likely to lead to democratization:2 In line with my causal mechanism I find that accounting for industrial worker revolts on the right-hand side of a regression equation accounts for a significant part of the effect of industrialization on democracy.

The paper makes several meaningful contributions to existing literatures. First, the paper contributes to the large literature on the economic roots of democracy. It does so by showing that industrialization has an important effect on democracy net of other, more widely studied, economic variables (e.g., income and inequality). It is important to note here that I see the role of industrialization as complementary (not as a substitute) to other more widely studied economic determinants of democracy. Indeed, it is perfectly possible that higher levels of income, equality, education, urbanization, and industrialization all to different degrees, and under different conditions, have an independent effect on democracy.

\footnotetext{
${ }^{1}$ That being said, most countries that are democracies today never reached high levels of industrialization, and must therefore have democratized for other reasons. Industrialization is thus far from the only factor that matters for democracy.

${ }^{2}$ This latter result was established before by Dahlum, Knutsen and Wig (2019).
} 
Second, the paper contributes by showing that China may be less of a deviant case than critics of modernization theory perceive it to be. The 2021 Chinese Statistical Yearbook suggests that approximately $22.3 \%$ of the Chinese workforce was employed in manufacturing in 2020. In the West, Taiwan, and South Korea at least 22.9\% - and typically more than 25\% - of the workforce was employed in manufacturing at the time of democratization (median=27.0\%; mean $=28.5 \%$ ) (see Table 1 below). While it is certainly true that China harbors a sizable group of manufacturing workers, China is also the largest country in the world. With the exception of Japan (which arguably democratized "early" because of unrelated processes triggered by its defeat in World War II) China is actually somewhat less industrialized than all of today's highly developed countries were when they democratized.

The paper is most closely related to the seminal work of Rueschemeyer, Stephens and Stephens (1992). Rueschemeyer, Stephens and Stephens (1992) argue that "capitalist development" defined as economic development driven by capital interests in competition with each other (p. 1)-leads to democracy because it increases the organizational capacity of the working class. While my theory is related through its focus on how economic development increases the organizational capacity of disenfranchised groups, it differs in terms of both the driving force and the causal mechanism linking economic development with democracy. Rather than "capitalist development," I identify manufacturing employment as the key independent variable. This is significant as capitalist development arguably includes many economic production processes that do little to change a country's socio-economic structure (e.g., tourism), or may, in fact, move a country's socio-economic structure in an anti-democratic direction (e.g., natural resource extraction - Ross (2015)). Furthermore, my theory is not restricted to the working class. A significant number of members of the urban middle class in highly industrialized countries work as managers and engineers in the manufacturing sector, and this group often plays an important role in the establishment of democracy $!^{3}$ If it was

${ }^{3}$ This only notably changes with the shift to modern service employment, which typically only occurs several decades after industrialization and democratization have already taken 
simply a working-class story - as opposed to a manufacturing story - one would expect to find employment in other more working-class dominated sectors (for example, mining) would also positively affect democracy. I do not find that to be the case.

My theory is also related to the seminal work of Llavador and Oxoby (2005). Llavador and Oxoby (2005) explain how partial extensions of the franchise in the $19^{\text {th }}$ century may have been the result of industrialists strategically enfranchising higher earning industrial workers, but not agricultural workers, to shift public spending towards public goods that large landowners opposed. Llavador and Oxoby s (2005) model is specific to the first wave of democratization (with its process of limited suffrage extensions) and to cases with powerful landed elites (which is not applicable to several important cases were industrialization plausibly led to democratization - e.g., South Korea). I show that industrialization can in fact explain transitions to full democracy in all waves of democratization. I do so by arguing that besides the top-down mechanism highlighted by Llavador and Oxoby (2005), industrialization also increases the pressure for democracy from below $f$

\section{Theory}

\subsection{Industrialization and the pressure for democratization}

Prior to democratization the government is typically controlled by a small group of capitalists and/or large landowners. Both these groups tend to strongly oppose democracy for two reasons. First, being a rich and small minority makes that the one-person, one-vote rule underlying democratic elections risks significant redistribution towards the poorer majority (Acemoglu and Robinson, 2006; Boix, 2003). Second, both capitalists and large landowers

\footnotetext{
place (see section 2.4 below).

${ }^{4}$ See online Appendix A for how my theory relates to the seminal work of Acemoglu and Robinson (2006), Ansell and Samuels (2014), Boix (2003), Inglehart and Welzel (2005),
} Lipset (1959), and Lizzeri and Persico (2004). 
tend to derive significant economic benefits from labor-repressive economic institutions that are difficult to sustain under democracy. These labor-repressive economic institutions tend to take the form of restrictions on labor migration in the case of large landowners, and little to no regulation on wages and working conditions for capitalists. While capitalists and large landowners may also sometimes have other opposing political-economic interests, these are typically not decisive enough for either group to band together with the masses and push for full democracy (Przeworski, 2009; Rueschemeyer, Stephens and Stephens, 1992).

While most ordinary people are typically disadvantaged under autocracy, manufacturing workers are especially likely to have a strong interest in political change under autocracy. First, manufacturing workers are due to the nature of their work at high risk of negative life-cycle shocks (e.g., unemployment, sickness) while they have neither the traditional coping mechanisms provided by agricultural communities (e.g., substituting wage labor for subsistence farming) nor the greater wealth of economic elites to effectively deal with such risks (Korpi, 2006). Second, factory work itself tends to generate particularly harsh socioeconomic conditions for manufacturing workers (e.g., long hours, little labor autonomy, and often a highly hierarchical and labor-repressive management regime). Manufacturing workers, therefore, tend to have a particularly strong interest in gaining power over government policies with regard to such issues as labor regulation, housing policy, welfare benefits, and equal/fair treatment by the justice system and the state more generally.

Rather than bargain for selective policy concessions by the existing autocratic regime or attempt to establish their own autocratic regime, manufacturing workers in highly industrialized countries are likely to demand democracy for two reasons. First, manufacturing workers are unlikely to be satisfied with selective policy concessions because selective policy concessions from a government controlled by a group with opposing economic interests cannot be credible in the long term (Acemoglu and Robinson, 2006). Second, establishing a regime that solely tailors to manufacturing workers' own interests is typically not feasible. Doing so would require the structural exclusion of all higher social classes, which, due to their stronger 
socio-economic position, generally have sufficient resources to remain politically influential (Rueschemeyer, Stephens and Stephens, 1992).

Conditional on being unable to exclude higher classes, manufacturing workers in highly industrialized countries have an interest in supporting a regime that would enfranchise all classes. In highly industrialized countries before democratization approximately $25 \%$ to $30 \%$ of the workforce is typically employed in manufacturing (see Table 1 below). At this stage of development poorer farmers, petty service workers, and paupers together typically represent more than 25\% but less than 50\% of the workforce (Osamu and Shaw-Taylor, Forthcoming). This suggest that manufacturing workers in highly industrialized countries not only typically incorporate the economic median voter position (which ensures them significant influence over government policy under the one-person, one-vote rule of democracy) $)^{5}$ but also that they would typically lose this position if they excluded any other social group (i.e., if they exclude the poor they would typically fall below the median voter position).

Industrialization not only generates the incentive to push for democracy, it also provides manufacturing workers with the organizational capacity to do so tion tends to be subject to a deep division of labor, significant economies of scale, and high

5 Ansell and Samuels (2014) argue that industrial workers cannot be motivated to push for democracy through this channel because they typically are still a small group situated well above the economic median voter at the time of democratization. They primarily come to this conclusion based on social tables from the United Kingdom in the year 1867. Importantly, however, the Reform Act of 1867 enfranchised only about $15 \%$ of the adult population. When the United Kingdom introduced universal suffrage in 1928, it employed approximately $34.7 \%$ of its workforce in manufacturing and this group almost certainly incorporated the economic median voter (see evidence from social tables in online Appendix B).

${ }^{6}$ This contrasts sharply with peasants, who tend to be the economic median voter prior to widespread industrialization. Dahlum, Knutsen and Wig (2019) find that significantly fewer mass revolts focused on political change originate among the peasantry, and that revolts dominated by peasants, if anything, tend to negatively affect democracy (Tables A.1, A.2, 
transaction costs. Manufacturing production, therefore, usually relies on large groups of people working together in big, complex, and impersonal organizations, agglomerated in urban areas (Krugman, 1993) I7 Making this work efficiently requires instilling workers and managers with a wide range of organizational and attitudinal capabilities that foster cooperation on a large and impersonal basis (e.g., negotiating and working together with strangers, dealing with disagreements, accepting authority, disciplining free riders). Many of these capabilities are transferable to mass organization in general and, therefore, can also be used to organize politically (Marx, 1867). It is no coincidence, therefore, that many significant "political" civil society organizations - for example, labor unions - traditionally originated in industry (Marks, 2016) 8 The agglomeration of manufacturing production in urban areas, meanwhile, lowers the cost of communication and congregation (Beissinger, Forthcoming) and raises the revolutionary risk of mass political protests (Aidt and Franck, 2019), further increasing manufacturing workers' capacity to successfully mobilize.

\subsection{Industrialization and the cost of suppression}

Industrialization not only increases the pressure for democracy from below, it also makes it more costly for elites to repress these demands.

As compared to other economic sectors manufacturing production tends to rely on significantly more forward and backward linkages (Hirschman, 1959). These supply-chain linkages make that economic production in highly industrialized countries is much more strongly disrupted by socio-political instability than economic production in non-industrialized societies (e.g., strikes in one industry directly affect many other industries that supply or demand

and A.28).

${ }^{7}$ Informal manufacturing, which typically represents only a small fraction of total manufacturing in highly industrialized countries, may be an exception to this.

${ }^{8}$ This is even while industrialists and autocratic elites typically do everything they can to suppress such organizations from originating in the first place (Marks, 2016). 
goods to/from the disrupted industry). $9^{9}$ Furthermore, because mass revolts in highly industrialized countries tend to be more frequent, larger, better coordinated, and closer to urban centers of power (Butcher and Svensson, 2016, Dahlum, Knutsen and Wig, 2019, Tilly, 1978)), repressing these protests is significantly more expensive in terms of police and defense costs 10

Thus, industrialization not only increases civil society's incentive and organizational capacity to generate mass political revolts, these industrialization-induced revolts also tend to be more costly for autocratic elites. Once the cost of repression rises sufficiently, autocratic elites find it in their own best interest to allow democracy as it is cheaper than continuing political repression (Boix, 2003, Rosendorff, 2001) .11

\subsection{Industrialization and democratic consolidation}

Manufacturing employment typically remains high for many decades after democratization. The same socio-economic structure that led to the initial democratic transition therefore remains largely intact, supporting democratic consolidation. Note, for example, that even in 1970, decades after their respective democratic transitions, manufacturing employment

\footnotetext{
${ }^{9}$ Manufacturing production is also unusually sensitive to political instability because unlike in many other sectors producers can postpone selling and consumers can postpone buying, because manufacturing is particularly capital-intensive, and because manufacturing is strongly affected by foreign demand and exchange-rate fluctuations (Eggers and Ioannides, 2006).

I0 Note that the cost of repression in autocracies is significant to begin with; even when holding income levels and exposure to warfare constant, autocracies spend about $40 \%$ more on their militaries than do democracies (Brauner, 2015).

${ }^{11}$ Note that the economic cost of democracy to elites is often relatively limited as they typically finds ways to remain influential under democracy (e.g., through campaign contributions or by embedding anti-majoritarian institutions in the new democratic constitution) (Albertus and Menaldo, 2018).
} 
in the United Kingdom, the United States, France, West Germany, and Sweden still stood at $31.7 \%, 22.2 \%, 25.4 \%, 35.8 \%$, and $28.2 \%$ respectively (calculated based on the 10 -sector database of the GGDC).

However, manufacturing employment does not remain consistently high over the course of a nation's economic development. Today, only around $10 \%$ of Western working populations are engaged in manufacturing 12 While this is still relatively high from a cross-national perspective, this does beg the question: What stabilizes democracy in the long term? Why would the middle class that is employed in the modern service sector in post-industrial societies not opt for a political regime that structurally excludes the lower classes? Such a bargain was ultimately preferred by many middle classes prior to deep and widespread industrialization (Rueschemeyer, Stephens and Stephens, 1992).

I argue that middle classes in post-industrial societies choose not to exclude the lower classes for two reasons.

First, middle class modern service workers in post-industrial societies have little incentive to disenfranchise the poorer segments of society because they tend to incorporate the economic median voter. Prior to industrialization, the middle class tends to be a small social group situated well above the median income (Ansell and Samuels, 2014). Universal suffrage for middle class actors prior to widespread industrialization thus means relinquishing significant control over socio-economic policies to the much more numerous and much poorer lower classes. After the shift from manufacturing employment to modern service employment has taken place, however, a majority of the population could reasonably be classified as middle

\footnotetext{
${ }^{12}$ The shift towards modern service employment is itself largely the result of successful industrialization. See Rowthorn and Wells (1987) for an excellent description of this process. ${ }^{13}$ It is possible that the fact that manufacturing employment typically remains high for several decades after democratization is in itself sufficient for democratic consolidation. Note, for example, that the probability of an authoritarian reversal is close to zero after a democracy has been in existence for more than 20 years (Svolik, 2008).
} 
class, and, therefore, the middle class always contains the economic median voter position. Under such conditions, universal suffrage relinquishes much less policy control to the poorer segments of society.

Second, middle class modern service workers in post-industrial societies have much less capacity to disenfranchise the poorer segments of society. Unlike the case of pre-industrial middle classes, the lower classes in post-industrial service economies are no longer poor farmers and petty service workers, instead, they are relatively well-organized and politically conscious construction, mining, manufacturing, and health care workers with significant disruptive capacity. Therefore, the poor and working class can no longer be excluded without significant costs to middle- and upper-class incomes (through, for example, strikes in crucial economic sectors).

\section{Measurement and Data}

Testing the effect of industrialization on democracy is made difficult by the fact that existing datasources do not provide data on manufacturing employment for before 1950, and for most countries only contain data since 1970, or even later. I circumvent this data challenge by scraping census data on manufacturing employment from the hardcopy accounts of Mitchell (2013), and by combining this data with manufacturing employment data from the UNIDO INDSTAT2 database and the GGDC 10-sector database.

Mitchell (2013), GGDC, and UNIDO all ensure, as best as possible, that their estimates on employment in the manufacturing sector remain comparable over time. Importantly, however, the UNIDO estimates for any given country-year tend to be marginally lower than the estimates from Mitchell (2013) and GGDC. This is because UNIDO classifies manufacturing workers on the basis of the nature of their job, rather than on the basis of whether they work for a company that is predominantly engaged in manufacturing. To avoid sudden jumps in the time-series due to changes in the data source, rather than real changes in a 
country' number of persons employed in manufacturing, I use in all cases one data source per country and add country fixed effects in all specifications. All results hold when creating the most extensive panel possible by imputing (in any order) the UNIDO, GGDC, and Mitchell (2013) data, and when restricting the analysis to the use of only one data source for the entire sample.

To choose which datasource to use for any individual country I simply select for each country the datasource that maximizes the number of years for which data for that individual country is available. Before doing so I linearly interpolate the data using the following two rules: (1) I drop country-years if the available data requires me to interpolate for more than 15 years; and (2) if (1) happens I also drop the years prior to this point to maintain a continuous time series for each country 14 All results hold with no or unrestricted interpolation.

Because UNIDO does not provide data on the total working population I account for differences in country size by calculating for each country-year the percentage of the total population that is employed in manufacturing. All results hold when using the population that is between 15 and 64 years of age as the denominator variable (but this data is not available for more than 40 countries for which data on total population is available).

To measure a country-year' level of democracy I use the liberal democracy index of the Varieties of Democracy (V-dem) Project. To aid the interpretation of substantive effects I rescale this variable to range from 0 to 10 (the original variable ranges from 0 to 1 ). To ensure that my results are not affected by the choice for this particular democracy indicator I run robustness checks with a large number of alternative democracy measures and find the results essentially unchanged (see Figure 1 below).

${ }^{14}$ The only exceptions to these rules are the United Kingdom and the Netherlands. For these countries I interpolate more than 15 years from 1931 to 1951 and from 1930 to 1947, respectively. Not doing so would drop 86 and 58 years of qualified data before WW II (which interrupted the censuses in these countries). Dropping these years makes no substantive difference to the results. 


\section{Identification strategy}

To examine the effect of industrialization on democracy I follow the existing literature by estimating the following equation with ordinary least squares (OLS): 15

$$
Y_{i t}=\beta_{0}+\beta_{1} Y_{i t-1}+\beta_{2} X_{i t-1}+\beta_{3} C_{i t-1}+\delta_{t}+\gamma_{i}+\epsilon_{i t}
$$

where $Y_{i t}$ is the level of liberal democracy in country $i$ and year $t . X_{i t-1}$ is the percentage

of the population engaged in manufacturing in country $i 5$ years prior to $t[16$ On the righthand side I include one lag of democracy (i.e., $Y_{i t-1}$ ) to account for serial autocorrelation and potential mean-reverting. After including one lag of democracy I find no economically or statistically significant effect of further lags of democracy and no evidence of serial autocorrelation in a Wooldridge autocorrelation test. Nonetheless all results hold with 2 to 5 lags of democracy on the right-hand side. $\delta$ in equation (1) are a full set of country fixed effects, $\gamma$ are a full set of time fixed effects, and $C_{i t-1}$ is a vector of time-varying control variables. I report standard errors that are robust against heteroskedasticity and serial correlation on the country level.17

I choose to focus on linear dynamic panel models with country and time fixed effects for two reasons. First, such models are easy to interpret. Second, this specification follows the precedent set by the current state-of-the-art econometric literature on the economic roots of democracy (e.g., Acemoglu et al. (2008), Boix (2011), and Treisman (2015)). Note, however, that imposing a linear functional form assumes that a decline in manufacturing employment always negatively affects democracy. In the context of my theory this is a very conservative

\footnotetext{
${ }^{15}$ Given that the time dimension is relatively large in my panel (1845-2015) I expect the influence of the Nickell bias to be negligible. As shown in Figure 1 the results hold when using GMM estimation.

${ }^{16}$ As shown in Figure 1 all results hold with longer and shorter time lags.

${ }^{17}$ Following the existing literature I estimate equation (1) in levels. Evidence from unit root tests suggests that this is appropriate given that the data is stationary.
} 
approach as my theory suggests that the higher labor productivity in manufacturing tends to generate a structural change in employment from manufacturing to modern services in highly industrialized countries which, importantly, still sustains democracy. In online Appendix G I find that taking this subtlety into account does indeed lead to slightly larger estimated effects. However, I judge these differences to be too small to warrant a substantially more complex econometric specification (the differences with the simpler linear model are generally not statistically significant and always remain below $10 \%$ of total effect size).

In terms of causal identification equation (1) removes three important sources of potential bias. First, because of the country fixed effects equation (1) controls by design for all potentially confounding factors that do not vary over the time period that countries are observed. This, for example, excludes the possibility that the correlation that I find between industrialization and democracy is due to historical factors that occurred before countries enter the sample (e.g., colonialism). Second, because of the time fixed effects equation (1) controls by design for all potentially confounding factors that affect all countries at the same point in time. This, for example, excludes the possibility that the correlation that I find between industrialization and democracy is due to factors related to the nature of the international system. Last, equation (1) controls for reversed causality by lagging the industrialization variable with 5 years 18 This guards against the possibility that the correlation that I find between industrialization and democracy is due to democracy inducing industrialization, rather than vice versa.

Given the lagged independent variable, country, and time fixed effects the only way how equation (1) can be biased is by factors that: (a) change over the time period that countries are observed; and (b) which affect both the level of democracy in $t$ and the level of industrialization 5 years prior to $t$. The key identifying assumption underlying my approach is thus the absence of time-varying confounders.

As is typical for country-level studies I am unable to provide a design-based solution

\footnotetext{
${ }^{18}$ This does require the assumption that serial autocorrelation is sufficiently accounted for.
} 
to the problem of time-varying confounders. To nonetheless minimize the possibility that the correlation that I find between industrialization and democracy is due to time-varying confounders I conduct three robustness checks. First, I control for a large number of timevarying factors that based on theoretical grounds may reasonably be expected to affect both industrialization and democracy. Second, I use the method of Oster (2019) to estimate how large selection on unobservables has to be, relative to that of observed control variables, to assign the entire correlation between industrialization and democracy to confounding (rather than causality). Last, I run robustness checks where I estimate the effect of industrialization on democracy in relatively short time frames (e.g., post-1975) were potentially time-varying confounders are less likely to have substantially changed. Taken together I believe that this provides the best possible evidence that can currently be collected regarding the long-term country-level effect of industrialization on democracy.

\section{Results}

\subsection{Level of industrialization at which today's highly developed countries democratized}

Before turning to the econometric results I analyze whether the historical record in terms of the level and timing of democratization in the currently highly developed countries makes sense from an industrialization point of view. To do so I plot the level of industrialization, income, equality, education, and urbanization, in the year that all currently highly developed countries in the West and East Asia introduced universal suffrage (which is typically taken as the year in which these countries became "full" democracies). For comparison I report in parentheses the percentage of countries that Freedom House codes as "not free" and which had a higher level of industrialization, income, equality, education, and urbanization in 2015.

As can be seen in Table 1 most countries in North-West Europe and the British offshoots democratized in and around the 1920s. This appears very difficult to explain when one 
focuses on income, inequality, education, and urbanization because most of these countries still had levels of income, equality, education, and urbanization at the time that are low even by the standard of many of today's autocratic developing countries. For example, even the United Kingdom (in many ways the first "economically developed" country) had only a level of income of $\$ 7,150$, a $\mathrm{V}$-dem equality score of $0.34{ }^{19}$, an average years of schooling of 5.2 , and an urbanization rate of $64.0 \%$ when it democratized in 1928 . More than $53.6 \%, 64.7 \%$, $67.6 \%$, and $32.1 \%$ of all autocracies in fact had a higher level of income, equality, education, and urbanization in 201520

When one, however, focuses on industrialization the timing of democratization among early developers makes a lot of sense since the Second Industrial Revolution, which had completely transformed the socio-economic structure of Western societies, had just ended by the 1920s, right before most early developers democratized ${ }^{21}$ And indeed in 1928, in the United Kingdom, approximately $34.7 \%$ of the working population was employed in manufacturing, which is about $12.4 \%$ higher than the most industrialized undemocratic country today (China).

Table 1 shows that the story for the late-developers in East Asia and Southern Europe is essentially the same. Spain and Portugal industrialized from the beginning of the 1960s until 1974 and democratized in 1975 and 1976 respectively. South Korea industrialized from 1963 to approximately the middle of the 1980s and held its first democratic election in 1988. Taiwan industrialized from the 1950s to the end of the 1980s and democratized in 1996. Furthermore, all late-developers democratized on levels of industrialization that

\footnotetext{
${ }^{19}$ I here use V-dem's equal distribution of resources index because Gini data is missing for many early developers at the time of democratization.

${ }^{20}$ These disparities are even starker if one considers the United Kingdom already a "full" democracy in the $19^{\text {th }}$ century.

${ }^{21}$ Of course I am not suggesting here that industrialization was, or ever is, the only cause of democracy. Another factor that clearly was important in this particular time period was the end of WWI.
} 
Table 1: Level of income, equality, education, urbanization, and industrialization at the time of democratization in currently highly developed countries.

\begin{tabular}{lcllllll}
\hline Country & Year & $\begin{array}{l}\text { GDP per } \\
\text { capita (PPP) }\end{array}$ & $\begin{array}{l}\text { Equality index } \\
\text { (V-Dem) }\end{array}$ & $\begin{array}{l}\text { Average years } \\
\text { of education }\end{array}$ & $\begin{array}{l}\text { \% of population } \\
\text { living in cities }\end{array}$ & $\begin{array}{l}\text { \% of workforc } \\
\text { in manufact }\end{array}$ \\
\hline \multicolumn{7}{c}{ Panel A: Selected major European countries } \\
Austria & 1920 & $\$ 2,352$ & $(76.8 \%)$ & $0.686(32.4 \%)$ & $5.9(58.8 \%)$ & $35.9(71.8 \%)$ & N/A \\
Belgium & 1949 & $\$ 6,585(53.6 \%)$ & $0.816(10.3 \%)$ & $6.7(47.1 \%)$ & $51.0(50.0 \%)$ & $37.7(0 \%)$ \\
France & 1946 & $\$ 5,413(55.4 \%)$ & $0.892(8.8 \%)$ & $4.3(79.4 \%)$ & $44.4(56.4 \%)$ & $22.9(0 \%)$ \\
Netherlands & 1922 & $\$ 5,266(55.4 \%)$ & $0.627(36.8 \%)$ & $4.2(79.4 \%)$ & $43.0(59.0 \%)$ & $25.4(0 \%)$ \\
Italy & 1946 & $\$ 2,915(69.6 \%)$ & $0.480(50.0 \%)$ & $4.2(79.4 \%)$ & $37.8(69.2 \%)$ & $22.8(0 \%)$ \\
Portugal & 1976 & $\$ 8,908(44.6 \%)$ & $0.753(19.1 \%)$ & $4.5(79.4 \%)$ & $20.4(89.7 \%)$ & $27.0(0 \%)$ \\
Spain & 1977 & $\$ 12,871(32.1 \%)$ & $0.815(10.3 \%)$ & $7.0(47.1 \%)$ & $52.4(50.0 \%)$ & $26.8(0 \%)$ \\
Sweden & 1922 & $\$ 4,382(57.1 \%)$ & $0.631(36.8 \%)$ & $4.9(79.4 \%)$ & $17.6(94.9 \%)$ & N/A \\
Switzerland & 1971 & $\$ 23,858(14.3 \%)$ & $0.962(0 \%)$ & $10.0(11.8 \%)$ & $30.6(80.8 \%)$ & $38.5(0 \%)$ \\
West Germany & 1949 & $\$ 4,674(55.4 \%)$ & $0.929(5.9 \%)$ & $7.0(47.1 \%)$ & N/A & $38.0(0 \%)$
\end{tabular}

Panel B: UK and British offshoots

\begin{tabular}{lclllllll} 
Australia & 1901 & $\$ 15,506(26.8 \%)$ & $0.716(23.5 \%)$ & $8.9(17.6 \%)$ & $61.8(34.6 \%)$ & N/A \\
Canada & 1921 & $\$ 5,587(55.4 \%)$ & $0.424(55.9 \%)$ & $5.6(61.8 \%)$ & $26.3(85.9 \%)$ & N/A \\
New Zealand & 1907 & $\$ 7,381(53.6 \%)$ & $0.623(36.8 \%)$ & $4.8(79.4 \%)$ & $52.7(50.0 \%)$ & $23.1(0 \%)$ \\
United Kingdom 1928 & $\$ 7,150(53.6 \%)$ & $0.348(64.7 \%)$ & $5.2(67.6 \%)$ & $64.0(32.1 \%)$ & $34.7(0 \%)$ \\
\multicolumn{2}{l}{ United States } & $1920^{\dagger}$ & $\$ 10,153(39.3 \%)$ & $0.333(67.6 \%)$ & $7.2(41.2 \%)$ & $35.6(71.8 \%)$ & $26.1(0 \%)$ \\
United States & 1965 & $\$ 21,390(19.6 \%)$ & $0.582(41.2 \%)$ & $10.4(8.8 \%)$ & $55.9(42.3 \%)$ & $27.9(0 \%)$
\end{tabular}

Panel C: East-Asian miracle economies

$\begin{array}{llllllll}\text { Japan } & 1952 & \$ 3,086(67.9 \%) & 0.931(4.4 \%) & 7.1(41.2 \%) & 38.6(69.2 \%) & 20.9(4.2 \%) \\ \text { South Korea } & 1988 & \$ 11,571(35.7 \%) & 0.753(19.1 \%) & 10.3(11.8 \%) & 56.7(42.3 \%) & 24.2(0 \%) \\ \text { Taiwan } & 1996 & \$ 27,312(14.3 \%) & 0.913(8.8 \%) & 9.9(14.7 \%) & 78.0(15.4 \%) & 32.2(0 \%)\end{array}$

Notes: Entry is year that currently highly developed countries introduced universal suffrage. Percentage of countries that Freedom House coded as "not free" in 2015 with an equal or higher level of income, equality, education, urbanization, and industrialization in parentheses. See online Appendix D for measurement of variables. If data is missing it is imputed from earlier or later years within a 5 year interval. N/A indicates that data is not available.

$\dagger$ Refers to the year that universal suffrage for whites was introduced. 
are virtually unprecedented by any autocratic country today ${ }^{22}$ Again this story would be difficult to tell when one focuses on income, inequality, education, or urbanization. For example: when South Korea democratized in 1988 it still had an average per capita income of "only" \$11,571, which even at the time was below that of countries such as Uruguay, Mauritius, Trinidad and Tobago, Barbados, Argentina, Seychelles, and Gabon.

\subsection{Industrialization as distinct from other economic determinants of democracy}

Before turning to the main results I econometrically test the claim that industrialization is not simply a proxy for other more widely studied economic determinants of democracy. To do so I examine the "within" R-squared of two-way fixed effects regressions of the percentage of the population engaged in manufacturing on income, inequality, education, and urbanization (in the same year), after purging the country and time fixed effects using Wooldridge s (1991) detrending method. This exercise suggests that changes in industrialization within countries over time only share $18.1 \%, 4.5 \%, 27.4 \%$, and $11.1 \%$ of their variance with respective changes in income, equality, education, and urbanization at the same point in time. This patterns arises because industrialized countries have historically reached high shares of employment in manufacturing several decades before they have reached high levels of income, equality, education, and urbanization (Osamu and Shaw-Taylor, Forthcoming).

\subsection{Fixed effects estimates of effect of industrialization on democ- racy}

Table 2 reports the main results. Here I regress the V-dem liberal democracy index on the percentage of the total population engaged in manufacturing, together with country and

${ }^{22}$ The exception is Japan which democratized in 1952 when it was still relatively little industrialized (arguably at least in part due to outside pressure after WWII). 
time fixed effects. ${ }^{23}$ To be able to compare the substantive size of effects I standardize all non-dichotomous variables using z-scores.

The coefficient in column (1) suggest that a standard deviation increase in the percentage of the population engaged in manufacturing (i.e., an increase of $4.1 \%$ ) leads on average to a 0.274 scale points increase of the liberal democracy index (rescaled to range from 0 to 10) in 5 years. This effect is statistically significant at the $1 \%$ confidence level.

0.274 is only the short-run (immediate) effect, however. Because the model includes a lag of the dependent variable we have to estimate the implied long-run effect (working through the autoregressive process of democracy) by estimating the following equation:

$$
\beta_{2} X_{i t-1} /\left(1-\beta_{1} Y_{i t-1}\right)
$$

where $X$ is $\%$ in manufacturing, $Y$ is democracy, and the $\beta$ 's are regression coefficients (Wooldridge, 2010).

As is shown at the bottom of column (1) of Table 2 the long-run effect of a standard deviation increase in industrialization is estimated to be 0.661 . This is an economically large, but not an implausibly large, effect. It suggests, for example, that if a country would progress from a largely agricultural society of say less than $1 \%$ of the total population engaged in the manufacturing sector (e.g., Afghanistan, Angola, Eritrea, Kenya, Kyrgyzstan, Yemen, Zambia in 2010) to a highly industrialized society of say $13 \%$ of the total population engaged in manufacturing (e.g., approximately the peak-level of industrialization reached by countries

\footnotetext{
${ }^{23}$ In my baseline sample I include country-years if they arguably have the sovereignty to decide upon their own regime type and data is available. This first condition excludes all ex-colonies during their respective periods of colonialization, countries that were occupied by Nazi Germany and Japan during WWII, Macao, Hong Kong after 1996, and the Soviet satellite states in Eastern Europe from 1945 to 1990. All results hold when including these cases. See online Appendix E for all the country-years included in the baseline sample.
} 
such as the France, Japan, and the United States, but lower than the peak-level reached by the United Kingdom) that its level of democracy would increase by approximately $18.9 \%$ of V'dem's full liberal democracy index. $18.9 \%$ is roughly equivalent to the difference in the level of democracy that existed between the United States and Jamaica in 2015.

In column (2) I add the natural log of GDP per capita, Gini inequality, average years of education, and urbanization as covariates. As can be seen the effect of industrialization remains highly statistically and economically significant after accounting for these other, more widely studied, economic determinants of democracy. Furthermore, the size of the coefficients indicates that the effect of industrialization on democracy is significantly stronger than these alternative determinants.

The effect of industrialization on democracy in columns (1) and (2) is causal to the extent that there exist no other factors that vary during the time that I observe each country and which affect both democracy at time $t$ and the level of industrialization 5 years prior to $t$. To gauge how plausible this assumption is I begin by adding a large number of time-varying control variables which the existing literature highlights as potential co-determinants of industrialization and democracy (see online Appendices $\mathrm{C}$ and $\mathrm{D}$ for the measurement and theoretical motivation behind these controls).

Reassuringly, the effect of industrialization on democracy remains highly statistically and economically significant, and changes very little in size, after controlling for: oil rents, the number of past transitions, economic recessions, the amount of years that the current regime is in place, private property rights security, international trade, whether a democracy functions under a constitution written by an outgoing autocratic elite, the degree of state ownership in the economy, political corruption, alignment to the West, and inter- and intrastate warfare (see columns $(3)-(6)$ ). Furthermore, interpreting the substantive size of the control variables suggest that the effect of industrialization on democracy is significantly larger than any of the alternative determinants of democracy included in Table 2 .

The fact that the correlation between industrialization and democracy remains after in- 
cluding these controls suggest that the effect of industrialization on democracy is not driven by factors that we know from existing research may well be correlated with both industrialization and democracy. This of course does not prove that there are no other, perhaps currently unknown, factors that vary over time and confound the relationship between industrialization and liberal democracy.

Excluding this possibility beyond any reasonable doubt would require a (natural) experiment which would purge such time-varying confounders through (partial) random assignment of industrialization across countries. Unfortunately such a (natural) experiment is, to the best of my knowledge, not available.

I therefore take a second-best approach and ask: how large should selection on unobserved time-varying confounders be, relative to the observed control variables in Table 2, to entirely explain away the effect of industrialization on democracy? To estimate this parameter I make use of the recently developed method of Oster (2019) ${ }^{24}$ In sum, Oster (2019) uses the observed correlation between the controls and industrialization to estimate how much stronger the correlation between industrialization and unobservables has to be to reduce the effect of industrialization on democracy to 0 . Oster's (2019) $\delta$ for each set of controls can be found at the bottom of Table 2. As can be seen I find that to assign the entire correlation between industrialization and democracy to confounding (rather than causality) the effect of time-varying unobserved confounders has to be at least 3 times stronger than the effect of country and time fixed effects and the strongest combination of control variables included in Table 2 ,

While I cannot exclude the possibility that such a strong confounder exist, this does indicate that for this to be true the existing literature on democracy and industrialization must have missed an extremely important co-determinant of industrialization and democracy outside the already substantial list of controls included in Table 2.

${ }^{24}$ This method is closely related to, and improves on, the seminal work of Altonji and Taber (2005). 
Table 2: The effect of industrialization on democracy.

\begin{tabular}{|c|c|c|c|c|c|c|}
\hline & $(1)$ & $(2)$ & $(3)$ & (4) & $(5)$ & (6) \\
\hline Democracy $_{t-1}$ & $\begin{array}{c}0.586^{* * *} \\
(0.039)\end{array}$ & $\begin{array}{c}0.565^{* * *} \\
(0.043)\end{array}$ & $\begin{array}{c}0.599 * * * \\
(0.046)\end{array}$ & $\begin{array}{c}0.536^{* * *} \\
(0.049)\end{array}$ & $\begin{array}{c}0.548^{* * *} \\
(0.042)\end{array}$ & $\begin{array}{c}0.583^{* * *} \\
(0.039)\end{array}$ \\
\hline$\%$ in manufacturing $t-1$ & $\begin{array}{c}0.274^{* *} \\
(0.091)\end{array}$ & $\begin{array}{c}0.457^{* * *} \\
(0.129)\end{array}$ & $\begin{array}{c}0.309^{* *} \\
(0.102)\end{array}$ & $\begin{array}{l}0.248^{*} \\
(0.111)\end{array}$ & $\begin{array}{l}0.257^{* *} \\
(0.092)\end{array}$ & $\begin{array}{c}0.274^{* *} \\
(0.098)\end{array}$ \\
\hline Gini income inequality $t-1$ & & $\begin{array}{c}0.273 \\
(0.172)\end{array}$ & & & & \\
\hline Log GDP per capita $t_{t-1}$ & & $\begin{array}{c}-0.422^{*} \\
(0.201)\end{array}$ & & & & \\
\hline Years of education $t-1$ & & $\begin{array}{l}0.363 \\
(0.305)\end{array}$ & & & & \\
\hline Urbanization rate $_{t-1}$ & & $\begin{array}{l}0.325 \\
(0.182)\end{array}$ & & & & \\
\hline Oil rents (\% of GDP) ${ }_{t-1}$ & & & $\begin{array}{l}-0.011 \\
(0.062)\end{array}$ & & & \\
\hline No. of past transitions $t-1$ & & & $\begin{array}{c}0.287^{* * *} \\
(0.073)\end{array}$ & & & \\
\hline Economic crisis $_{t-1}$ & & & $\begin{array}{c}0.000 \\
(0.072)\end{array}$ & & & \\
\hline Duration regime $t-1$ & & & & $\begin{array}{l}-0.190^{*} \\
(0.073)\end{array}$ & & \\
\hline Property rights security $t-1$ & & & & $\begin{array}{c}0.213 \\
(0.165)\end{array}$ & & \\
\hline Trade $(\% \text { of GDP })_{t-1}$ & & & & $\begin{array}{l}-0.035 \\
(0.032)\end{array}$ & & \\
\hline Authoritarian constitution $_{t-1}$ & & & & & $\begin{array}{c}0.134 \\
(0.196)\end{array}$ & \\
\hline State control of economy $t-1$ & & & & & $\begin{array}{c}0.127 \\
(0.096)\end{array}$ & \\
\hline Political corruption $t-1$ & & & & & $\begin{array}{c}-0.408^{* * *} \\
(0.116)\end{array}$ & \\
\hline Aligned to West ${ }_{t-1}$ & & & & & & $\begin{array}{l}-0.124 \\
(0.125)\end{array}$ \\
\hline Inter-state warfare $t-1$ & & & & & & $\begin{array}{l}-0.260^{*} \\
(0.120)\end{array}$ \\
\hline Intra-state warfare $t-1$ & & & & & & $\begin{array}{l}-0.044 \\
(0.148)\end{array}$ \\
\hline $\begin{array}{l}\text { Implied long-run effect of } \\
\% \text { in manufacturing } t-1\end{array}$ & $\begin{array}{c}0.661^{* *} \\
(0.230)\end{array}$ & $\begin{array}{c}1.050^{* * *} \\
(0.309)\end{array}$ & $\begin{array}{c}0.771^{* *} \\
(0.267)\end{array}$ & $\begin{array}{l}0.534^{*} \\
(0.254)\end{array}$ & $\begin{array}{c}0.569^{* *} \\
(0.212)\end{array}$ & $\begin{array}{c}0.656^{* *} \\
(0.246)\end{array}$ \\
\hline Country fixed effects & Yes & Yes & Yes & Yes & Yes & Yes \\
\hline Time fixed effects & Yes & Yes & Yes & Yes & Yes & Yes \\
\hline Oster $\delta\left(\mathrm{R}^{2} \max =1\right)$ & - & - & 3.6 & 3.7 & 3.6 & 2.6 \\
\hline Observations & 1292 & 773 & 1035 & 1078 & 1134 & 1292 \\
\hline Countries & 145 & 87 & 126 & 128 & 135 & 145 \\
\hline
\end{tabular}

Notes: OLS regressions. The dependent variable is the liberal democracy index of V-dem. See online Appendix D for measurement of control variables. Data is observed in years ending with 0 and 5's (i.e., 5 year regular intervals). Robust standard errors clustered on the country level in parentheses.

$* * * \mathrm{p}<0.001, * * \mathrm{p}<0.01, * \mathrm{p}<0.05$. 


\subsection{Robustness checks}

In Figure 1 I find that the effect of industrialization on democracy is highly robust to: (1) omitting any particular world region from the sample; (2) examining the effect only in particular time periods (e.g., third wave of democratization); (3) using a balanced sample from 1960 to 2000 (as in Acemoglu et al. (2008)); (4) using longer or shorter lag lengths;

(5) using different democracy indicators (e.g., combined Polity IV index); and (6) using alternative dynamic panel estimators (e.g., the "difference" GMM estimator) ${ }^{25}$

\footnotetext{
${ }^{25}$ In online Appendix H I examine the effect when controlling for the percentage employed in agriculture and mining, and when controlling for manufacturing output. I here find that it is manufacturing employment that is driving the effect, and that they other factors have, if anything, a negative effect on democracy after accounting for manufacturing employment.
} 
Figure 1: Robustness checks.

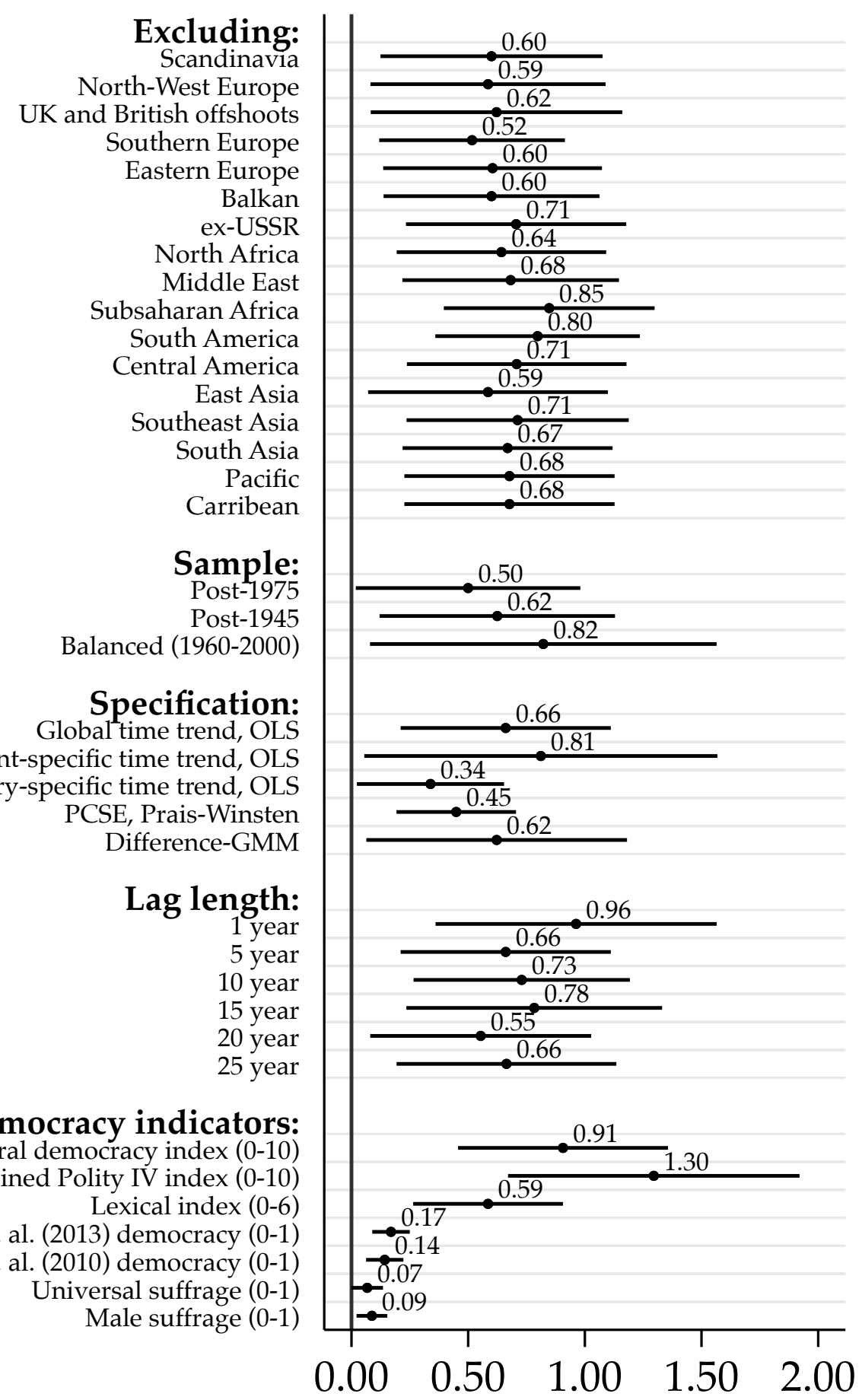

Notes: Implied long-run effect of industrialization on democracy estimated using a dynamic panel model with country and time fixed effects. Circles denote regression coefficients standardized using z-scores. 95\% confidence intervals are denoted by lines. Each row refers to a separate regression. Confidence intervals are robust against heteroscedasticity and autocorrelation on the country level. 


\subsection{Treatment heterogeneity}

In Table 3 columns (1) and (2) I examine whether the effect of industrialization on democracy varies depending on whether one is focusing on transitions to or consolidations of democracy (as is suggested by Przeworski and Limongi (1997) and Houle (2009) with regard to the relationship between income, inequality, and democracy). To do so I regress democracy on the level of industrialization in $t-1$ interacted with the level of democracy in $t-1$ (together with country and time fixed effects). This approach thus examines whether the effect of industrialization on democracy depends on whether a country was more/less democratic when the change in the level of industrialization occurred. In column (1) I simply use the continuous V-dem liberal democracy index. In column (2) I more neatly separate countries into discrete democratic and non-democratic categories using the dichotomous democracy measure of Boix, Miller and Rosato (2013). As can be seen in columns (1) and (2) both interaction effects are highly statistically and economically insignificant, suggesting that industrialization has an equally large effect on both transitions to and consolidations of democracy.

In column (3) I examine to what extent the effect of industrialization on democracy is contingent on state dependency. Bellin (2000) and O'Donnell (1973), among others, have suggested that industrialization under conditions of late development may have very different, and decisively less benevolent, effects on democracy. In sum, the argument is that late developers sought to industrialize under conditions of much greater market integration and competition of vastly more superior producers abroad. Manufacturing workers and industrialists were therefore heavily dependent on the state for protection to survive. This dependency on the state in turn made it less likely that industrialization generated an autonomous social group with the interest and capacity to push for democracy (because nobody wants to bite the hand that feeds him).

Cross-country measures of the degree to which country' manufacturing sectors are state dependent are, to the best of my knowledge, not available. I therefore proxy this variable 
using V-dem expert survey data on the degree to which the state owns or otherwise controls productive capital in the economy (this variable can unfortunately not be disaggregated to the manufacturing sector in particular) ${ }^{26}$ As can be seen in column (3) at least this measure of (general) state dependency does not significantly moderate the effect of industrialization.

While better measures of state dependency are desired one plausible explanation for this finding is that state dependency is in itself affected by successful industrialization. While import substitution industrialization in Latin America and command industrialization in the Soviet Union was heavily state dependent, so was the process of industrialization in many of the countries that did become well-functioning democracies shortly after industrialization. The governments of South Korea, Taiwan, and Japan made widespread use of selective subsidies and tariffs protections to develop their manufacturing sector. Furthermore, many of the key industries that drove industrialization in these countries were entirely or in large part state-owned. While often underlighted, many manufacturing industries in the early developers, including in Britain and the United States, also heavily relied on selective tariff protection, state-sponsored industrial espionage, and large government subsidies (Chang, 2002). Crucially, however, in the truly successful industrializers this state dependence lessened over time precisely because successful industrialization made the manufacturing sector competitive enough to flourish without the help of state support. In line with this interpretation my data suggests that none of the cases that Bellin (2000) and O'Donnell (1973) study to substantiate their hypothesis in fact ever reached close to the level of industrialization that existed in the currently highly developed countries in the West and East Asia before they democratized 27

\footnotetext{
${ }^{26}$ Note that employment in state-owned enterprises is regularly used to measure "state dependency" in individual-level studies on support for democratization (e.g., Rosenfeld (2021)). ${ }^{27}$ The same argument is likely to apply to the USSR. While reliable data on manufacturing employment in the USSR is largely missing, the most credible data provided by Kouwenhoven (1997) suggests that approximately $21.2 \%$ of the Soviet workforce worked in manufacturing in 1987. As is shown in Table 1 this is still well below the level of industrialization that existed
} 
Table 3: Heterogeneity across democratic transitions/consolidations and state dependency.

\begin{tabular}{|c|c|c|c|}
\hline & $(1)$ & $(2)$ & $(3)$ \\
\hline$\%$ in manufacturing $t-1$ & $\begin{array}{l}0.341^{*} \\
(0.147)\end{array}$ & $\begin{array}{c}0.110^{* * *} \\
(0.033)\end{array}$ & $\begin{array}{r}0.283^{* *} \\
(0.090)\end{array}$ \\
\hline V-dem liberal democracy $t-1$ & $\begin{array}{c}0.591^{* * *} \\
(0.039)\end{array}$ & & $\begin{array}{c}0.589^{* * *} \\
(0.041)\end{array}$ \\
\hline $\begin{array}{l}\text { V-dem liberal democracy } t-1 \text { * } \\
\% \text { in manufacturing } t-1\end{array}$ & $\begin{array}{l}-0.017 \\
(0.028)\end{array}$ & & \\
\hline Boix et. al. (2013) democracy $t-1$ & & $\begin{array}{c}0.442^{* * *} \\
(0.046)\end{array}$ & \\
\hline $\begin{array}{l}\text { Boix et. al. (2013) democracy } t-1 \text { * } \\
\% \text { in manufacturing } t-1\end{array}$ & & $\begin{array}{l}-0.025 \\
(0.041)\end{array}$ & \\
\hline State control of economy $t-1$ & & & $\begin{array}{c}0.025 \\
(0.089)\end{array}$ \\
\hline $\begin{array}{l}\text { State control of economy } t-1 \\
\% \text { in manufacturing }{ }_{t-1}\end{array}$ & & & $\begin{array}{l}-0.074 \\
(0.061)\end{array}$ \\
\hline $\begin{array}{l}\text { Implied long-run effect of } \\
\% \text { in manufacturing } t-1\end{array}$ & $\begin{array}{l}0.834^{*} \\
(0.378)\end{array}$ & $\begin{array}{c}0.196^{* * *} \\
(0.057)\end{array}$ & $\begin{array}{r}0.689^{* *} \\
(0.234)\end{array}$ \\
\hline Country fixed effects & Yes & Yes & Yes \\
\hline Time fixed effects & Yes & Yes & Yes \\
\hline Observations & 1292 & 1251 & 1292 \\
\hline Countries & 145 & 143 & 145 \\
\hline
\end{tabular}

Notes: OLS regressions. The dependent variable is the liberal democracy index of V-dem in columns (1) and (3). The dependent variable in column (2) is the dichotomous democracy variable of Boix, Miller and Rosato (2013). Data is observed in years ending with 0 and 5's (i.e., 5 year regular intervals). Robust standard errors clustered on the country level in parentheses.

$* * * \mathrm{p}<0.001, * * \mathrm{p}<0.01, * \mathrm{p}<0.05$.

\subsection{Causal mechanism}

A high share of employment in manufacturing can in principle positively affect democracy through many different complementary causal mechanisms. My theory emphasizes how in-

in all currently highly developed countries before they democratized (with the exception of Japan). In Germany $30.8 \%$ of the working population was employed in manufacturing in 1933. This case thus does contradict the theory. Germany before WWII may be a true outlier. Alternatively, it could be the case that industrialization did in fact push Germany into a pro-democratic direction, but that this effect was temporarily overwhelmed by the major anti-democratic effect of Germany's defeat in WWI (as convincingly argued by Berman (2001)). 
dustrialization tends to politically mobilize manufacturing workers in favor of democracy. If this is true one would expect to find: (a) that industrialization strongly increases the probability of mass revolts dominated by industrial workers; (b) that mass revolts dominated by industrial workers tend to induce democracy; and (c) that including mass revolts dominated by industrial workers on the right-hand side of a regression equation accounts for a significant part of the effect of industrialization on democracy.

I now test these expectations empirically.

To measure mass revolts by industrial workers I use Dahlum, Knutsen and Wig]s (2019) data on the socio-economic make-up of mass political protests in 147 countries from 1900 to 2006. Because Dahlum, Knutsen and Wig (2019) only code very large political protests their data is relatively sparse (only 82 mass revolts dominated by industrial workers are recorded). I therefore collapse the data in 3 year simple moving averages and code a dummy that takes the value 1 if any mass political protest dominated by industrial workers has occurred in any of the past three years, and 0 otherwise.

In Table 4 column (1) I regress this industrial workers revolt dummy on the average level of industrialization during the same 3 year period (this is appropriate as I expect industrialization to directly lead to greater mobilization, rather than with a time lag). In line with my theory I find that industrialization strongly increases the probability of a mass political protest dominated by industrial workers. Substantially, a standard deviation increase in the fraction of the population engaged in manufacturing increases the probability of industrial worker revolts by $1.9 \%$. This is a very large effect as the baseline probability of at least 1 mass political protest dominated by industrial workers is only $0.9 \%$.

In column (2) I regress the V-dem liberal democracy index on industrial worker revolts. In line with the results of Dahlum, Knutsen and Wig (2019) I find that industrial worker revolts are very strongly correlated with democracy - at least one industrial worker revolt in the past 3 years increases the $\mathrm{V}$-dem liberal democracy index with 1.6 points or approximately 0.6 standard deviation. 
Table 4: Industrialization, mass revolts by industrial workers, and democracy.

\begin{tabular}{|c|c|c|c|c|}
\hline \multirow[t]{2}{*}{ Dependent variable: } & \multirow{2}{*}{$\begin{array}{l}\text { Industrial worker } \\
\text { revolt }(0-1)_{t-1} \\
(1)\end{array}$} & \multicolumn{3}{|c|}{$\begin{array}{l}\text { Liberal democracy } \\
\text { index (V-dem) }\end{array}$} \\
\hline & & $(2)$ & $(3)$ & (4) \\
\hline Democracy $t-1$ & $\begin{array}{c}-0.016^{* * *} \\
(0.005)\end{array}$ & $\begin{array}{c}0.824^{* * *} \\
(0.027)\end{array}$ & $\begin{array}{c}0.802^{* * *} \\
(0.026)\end{array}$ & $\begin{array}{c}0.828^{* * *} \\
(0.026)\end{array}$ \\
\hline Industrial worker revolt $t-2$ & $\begin{array}{l}0.215^{*} \\
(0.087)\end{array}$ & & & \\
\hline Industrial worker revolt ${ }_{t-1}$ & & $\begin{array}{c}1.620^{* * *} \\
(0.429)\end{array}$ & & $\begin{array}{c}1.654^{* * *} \\
(0.453)\end{array}$ \\
\hline$\%$ in manufacturing $t-1$ & $\begin{array}{l}0.019^{*} \\
(0.009)\end{array}$ & & $\begin{array}{c}0.175^{* *} \\
(0.066)\end{array}$ & $\begin{array}{l}0.144^{*} \\
(0.064)\end{array}$ \\
\hline Country fixed effects & Yes & Yes & Yes & Yes \\
\hline Time fixed effects & Yes & Yes & Yes & Yes \\
\hline Observations & 1831 & 1936 & 1827 & 1827 \\
\hline Countries & 136 & 136 & 135 & 135 \\
\hline
\end{tabular}

Notes: OLS regressions. Dependent variable in column heading. Data is in 3 year simple moving averages. Robust standard errors clustered on the country level in parentheses.

$* * * \mathrm{p}<0.001, * * \mathrm{p}<0.01, * \mathrm{p}<0.05$.

Running a formal mediation analysis is arguably of limited utility in this case because industrialization is likely to affect democracy through many other industrial worker revolts outside the major ones that are recorded by Dahlum, Knutsen and Wig (2019). The results in Table 4 nonetheless suggest that even the 82 mass industrial worker revolts coded by Dahlum, Knutsen and Wig (2019) account for more than $18 \%$ of the direct effect of industrialization on democracy (see decline in industrialization coefficient between columns (3) and (4)). Assuming sequential ignorability this suggests that mass revolts by industrial workers mediate at least some of the effect of industrialization on democracy.

\section{Conclusion}

Understanding why some countries are well-functioning democracies while other countries are autocracies is a major concern in comparative politics, and is of paramount importance for understanding the root causes of the major differences in human welfare across countries and over time. This paper contributes to this endeavor by showing that industrializationdefined as a large share of employment in manufacturing - is a highly robust determinant of 
democracy.

My empirical aim in this paper was to test whether industrialization is robustly correlated with democracy across a large number of countries and over a long period of time. Future research may fruitfully contribute by discovering ways to causally identify the effect of industrialization. Future research is also necessary with regard to the important question of whether the average effect of industrialization on democracy that I recover varies across specific types of (de)industrialization (e.g., state versus market-led industrialization, export-oriented versus import-substitution industrialization, premature versus mature deindustrialization) and/or across different forms of manufacturing (e.g., high- versus low-tech, heavy- versus light industry).

The results have several important policy implications. This is particularly the case in light of the ongoing public policy debate on whether industrialization is still an important goal in itself, or whether poor countries may instead be able to reach Western standards of living by moving directly into a service economy (Ghani and O'Connell, 2014). Besides the economic question whether it is in fact true that countries can in the long-run reach high levels of development without industrializing my results suggest that a "post-industrial" development strategy may have large unintended political consequences as industrialization has historically been an important path towards well-functioning democratic institutions. 


\section{References}

Acemoglu, Daron and James A. Robinson. 2006. Economic Origins of Dictatorship and Democracy. Cambridge University Press.

Acemoglu, Daron, Simon Johnson, James A. Robinson and Pierre Yared. 2005. "From Education to Democracy?" American Economic Review 95(2):44-49.

Acemoglu, Daron, Simon Johnson, James A. Robinson and Pierre Yared. 2008. "Income and Democracy." American Economic Review 98(3):808-42.

Ahn, Chung-Si. 1997. Economic Dimensions of Democratization in South Korea. In Democratization in Southeast and East Asia, ed. Anek Laothamatas. Silkworm Books pp. 237-258.

Aidt, Toke S and Raphaël Franck. 2019. "What Motivates an Oligarchic Elite to Democratize? Evidence from the Roll Call Vote on the Great Reform Act of 1832." Journal of Economic History 79(3):773-825.

Albertus, Michael and Victor Menaldo. 2018. Authoritarianism and the Elite Origins of Democracy. Cambridge University Press.

Altonji, Joseph G., Todd E. Elder and Christopher R. Taber. 2005. "Selection on Observed and Unobserved Variables: Assessing the Effectiveness of Catholic Schools." Journal of Political Economy 113(1):151-184.

Ansell, Ben W. and David J. Samuels. 2014. Inequality and Democratization: An EliteCompetition Approach. Cambridge University Press.

Armstrong, Charles K. 2007. Korean Society: Civil Society, Democracy, and the State. Routledge.

Beissinger, Mark. Forthcoming. The Revolutionary City: Urbanization and the Global Transformation of Rebellion. Princeton University Press.

Bellin, Eva. 2000. "Contingent Democrats: Industrialists, Labor, and Democratization in Late-Developing Countries." World Politics 52(2):175-205.

Berman, Sheri E. 2001. "Modernization in Historical Perspective: The Case of Imperial Germany." World Politics pp. 431-462. 
Boix, Carles. 2003. Democracy and Redistribution. Cambridge University Press.

Boix, Carles. 2011. "Democracy, Development, and the International System." American Political Science Review 105(4):809-828.

Boix, Carles, Michael K. Miller and Sebastian Rosato. 2013. "A Complete Data Set of Political Regimes, 1800-2007." Comparative Political Studies 46(12):1523-1554.

Boix, Carles and Susan C. Stokes. 2003. "Endogenous Democratization." World Politics $55(4): 517-549$.

Brauner, Jennifer. 2015. "Military Spending and Democracy." Defence and Peace Economics 26(4):409-423.

Butcher, Charles and Isak Svensson. 2016. "Manufacturing Dissent: Modernization and the Onset of Major Nonviolent Resistance Campaigns." Journal of Conflict Resolution 60(2):311-339.

Chang, Ha-Joon. 2002. Kicking Away the Ladder: Development Strategy in Historical Perspective. Anthem Press.

Cirone, Alexandra. 2021. "Under Pressure: Political Geography of Mobilization." Working Paper.

Dahlum, Sirianne, Carl H. Knutsen and Tore Wig. 2019. "Who Revolts? Empirically Revisiting the Social Origins of Democracy." Journal of Politics 81(4):1494-1499.

Dahlum, Sirianne and Tore Wig. 2019. "Educating Demonstrators: Education and Mass Protest in Africa." Journal of Conflict Resolution 63(1):3-30.

Dahlum, Sirianne and Tore Wig. 2021. "Chaos on Campus: Universities and Mass Political Protest." Comparative Political Studies 54(1):3-32.

Eggers, Andrew and Yannis M. Ioannides. 2006. "The Role of Output Composition in the Stabilization of US Output Growth." Journal of Macroeconomics 28(3):585-595.

Epstein, David L., Robert Bates, Jack Goldstone, Ida Kristensen and Sharyn O'Halloran. 2006. "Democratic Transitions." American Journal of Political Science 50(3):551-569.

Fresh, Adriane. 2022. "Population and Political Change in Industrial Britain." Working 
Paper.

Ghani, Ejaz and Stephen D. O'Connell. 2014. Can Service Be a Growth Escalator in LowIncome Countries? The World Bank Policy Research Working Paper No. 6971.

Glaeser, Edward L., Giacomo A.M. Ponzetto and Andrei Shleifer. 2007. "Why does Democracy Need Education?" Journal of Economic Growth 12(2):77-99.

Hirschman, Albert O. 1959. The Strategy of Economic Development. Yale University Press.

Houle, Christian. 2009. "Inequality and Democracy: Why Inequality Harms Consolidation but Does Not Affect Democratization." World Politics 61:589.

Huntington, Samuel P. 1991. The Third Wave: Democratization in the Late Twentieth Century. University of Oklahoma Press.

Inglehart, Ronald and Christian Welzel. 2005. Modernization, Cultural Change, and Democracy: The Human Development Sequence. Cambridge University Press.

Kim, Sunhyuk. 2000. The Politics of Democratization in Korea: The Role of Civil Society). University of Pittsburgh Press.

Korpi, Walter. 2006. "Power Resources and Employer-Centered Approaches in Explanations of Welfare States and Varieties of Capitalism: Protagonists, Consenters, and Antagonists." World Politics 58(2):167-206.

Kouwenhoven, Remco. 1997. "A Comparison of Soviet and US Industrial Performance: 192890." Working Paper. Groningen Growth and Development Centre. Research Memorandum GD-29.

Krugman, Paul R. 1993. Geography and Trade. MIT press.

Lipset, Seymour M. 1959. "Some Social Requisites of Democracy: Economic Development and Political Legitimacy." American Political Science Review 53(1):69-105.

Lizzeri, Alessandro and Nicola Persico. 2004. "Why Did the Elites Extend the Suffrage? Democracy and the Scope of Government, with an Application to Britain's "Age of Reform"." Quarterly Journal of Economics 119(2):707-765.

Llavador, Humberto and Robert J. Oxoby. 2005. "Partisan Competition, Growth, and the 
Franchise." Quarterly Journal of Economics 120(3):1155-1189.

Marks, Gary W. 2016. Unions in Politics. Princeton University Press.

Marx, Karl. 1867. Capital: Critique of Political Economy. Penguin Classics.

Miller, Michael K. 2012. "Economic Development, Violent Leader Removal, and Democratization." American Journal of Political Science 56(4):1002-1020.

Mitchell, Brian. 2013. International Historical Statistics. Palgrave Macmillan.

O’Donnell, Guillermo A. 1973. Modernization and Bureaucratic-Authoritarianism: Studies in South American Politics. Berkeley: Institute of International Studies, University of California.

Osamu, Saito and Leigh Shaw-Taylor. Forthcoming. Occupational Structure and Industrialization in a Comparative Perspective. Cambridge University Press.

Oster, Emily. 2019. "Unobservable Selection and Coefficient Stability: Theory and Evidence." Journal of Business 83 Economic Statistics 37(2):187-204.

Przeworski, Adam. 2009. "Conquered or Granted? A History of Suffrage Extensions." British Journal of Political Science 39(2):291-321.

Przeworski, Adam and Fernando Limongi. 1997. "Modernization: Theories and Facts." World Politics 49(2):155-183.

Rosendorff, B. Peter. 2001. "Choosing Democracy." Economics 83 Politics 13(1):1-29.

Rosenfeld, Bryn. 2021. "State Dependency and the Limits of Middle Class Support for Democracy." Comparative Political Studies 54:411-444.

Ross, Michael L. 2015. "What Have we Learned About the Resource Curse?" Annual Review of Political Science 18:239-259.

Rowthorn, Bob and John R. Wells. 1987. De-Industrialization Foreign Trade. Cambridge University Press.

Rueschemeyer, Dietrich, Evelyne H. Stephens and John D. Stephens. 1992. Capitalist Development and Democracy. Cambridge University Press.

Svolik, Milan. 2008. "Authoritarian Reversals and Democratic Consolidation." American 
Political Science Review pp. 153-168.

Tilly, Charles. 1978. From Mobilization to Revolution. New York: Random House.

Treisman, Daniel. 2015. "Income, Democracy, and Leader Turnover." American Journal of Political Science 59(4):927-942.

Wooldridge, Jeffrey M. 1991. "A Note on Computing R-squared and Adjusted R-squared for Trending and Seasonal Data." Economics Letters 36(1):49-54.

Wooldridge, Jeffrey M. 2010. Econometric Analysis of Cross Section and Panel Data. MIT press. 


\title{
- Online Appendix - Industrialization and Democracy
}

\author{
By: Sam van Noort
}

\section{Contents}

A Relationship with existing literature on the economic roots of democracy 1

A.1 Acemoglu and Robinson (2006), Ansell and Samuels (2014), and Boix (2003) 1

A.2 Inglehart and Welzel (2005) . . . . . . . . . . . . . . . . . 2

A.3 Lipset (1959) . . . . . . . . . . . . . . . . . . . . . . . . . 3

A.4 Lizzeri and Persico (2004) . . . . . . . . . . . . . . . . . . 4

\begin{tabular}{ll}
\hline B Social tables of the United Kingdom in 1928 & 5
\end{tabular}

\begin{tabular}{ll|l|l|l|l|l}
\hline C & Theoretical motivation behind control variables & 7
\end{tabular}

$\begin{array}{lr}\text { D Measurement of control variables } & 12\end{array}$

\begin{tabular}{lr}
\hline E Country-years included in sample & 15
\end{tabular}

\begin{tabular}{llr}
\hline F & Descriptive statistics & 16
\end{tabular}

\begin{tabular}{ll}
\hline G Accounting for mature deindustrialization & 17
\end{tabular}

H Controls for mining/agricultural employment and manufacturing output 19 


\section{A Relationship with existing literature on the economic roots of democracy}

Much has been written about the relationship between economic development and democracy. It is useful therefore to explicitly outline how my theory on the relationship between a shift towards a large share of employment in manufacturing (i.e., industrialization) and democracy differs from closely related work on the economic roots of democracy. I here do so by discussing how my theory differs from the seminal work of Acemoglu and Robinson (2006), Ansell and Samuels (2014), Boix (2003), Inglehart and Welzel (2005), Lipset (1959), and Lizzeri and Persico (2004).

\section{A.1 Acemoglu and Robinson (2006), Ansell and Samuels (2014), and Boix (2003)}

There exists a large literature on the relationship between economic inequality and democracy. The seminal references for this literature are: Acemoglu and Robinson (2006), Ansell and Samuels (2014), and Boix (2003)!

This literature is highly diverse but in the aggregate differs from my theory in three fundamental ways. First, I focus on employment patterns, as opposed to output (income/wealth) patterns. Second, I focus on the level of industrialization, as opposed to the distribution of income/wealth. Third, my theory focuses on how industrialization changes both the incentive and the capacity of different social groups to push in favor or against democracy. Acemoglu and Robinson (2006), Ansell and Samuels (2014), and Boix (2003) focus only on the incentive of different groups to favor or oppose democracy (this incentive, in these theories, is affected by different degrees and structures of economic inequality). ${ }^{2}$

\footnotetext{
${ }^{1}$ See also Freeman and Quinn (2012), Houle (2009), and Rosendorff (2001), among others.

${ }^{2}$ In Ansell and Samuels' (2014) theory inequality is not in itself causing democracy. Instead, rapidly increasing inequality is simply proxying for an economically rising yet politically disenfranchised social group which has an incentive to push for enfranchisement in order to protect its newly acquired wealth.
} 


\section{A.2 Inglehart and Welzel (2005)}

With Inglehart and Welzel (2005) I share the belief that industrialization plays an important role in democratization. Crucially, however, Inglehart and Welzel (2005) argue that a shift from agricultural employment to industrial employment leads to secular-rational values which retard democracy (see, for example, pages 36 and 59). For Inglehart and Welzel (2005) it is only a shift away from industrial employment towards modern service employment that leads to democracy because, they argue, post-industrial service work tends to induce selfexpressive values. I differ in two fundamental ways from this perspective.

First, my theory and empirical results directly contradict Inglehart and Welzel's (2005) expectation that a decline in industrial employment leads to democracy (conditional on having achieved a high level of industrialization in the past). Instead, I find an unconditionally and very large positive effect of the percentage employed in manufacturing on democracy. This result makes sense from a historic point of view. Note, for example, that the postindustrial service economy, as well as the post-material "self-expressive" values highlighted by Inglehart and Welzel (2005), only arose decades after all currently highly developed countries in the West and East Asia had already democratized (i.e., after +/- 1960 in the West, after +/- 1980 in Japan, and after +/- 2000 in South Korea and Taiwan).

Second, I differ on the mechanism through which economic development induces democracy. Inglehart and Welzel (2005) argue that economic development leads to an increased sense of economic security, which in turn leads to "self-expressive" values, which, they assume, are sufficient for democracy to be established and sustained. This implicitly assumes that the wealthiest people in society are the strongest proponent of democracy (as they are economically most secure), which is in direct contradiction with existing theory and empirical

evidence (e.g., Acemoglu and Robinson (2006), Boix (2003), Rueschemeyer, Stephens and Stephens (1992)). My theory takes a political economy approach, focusing on how industrialization changes the incentive and capacity of different social groups to support/oppose democracy; which is in line with much of the existing literature and evidence on democracy. 


\section{A.3 Lipset (1959)}

I share with Lipset (1959) the belief that economic development tends to make democratic forms of government more likely. My theory nonetheless differs from Lipset (1959) in two fundamental ways.

First, my theory differs with regard to what particular type/form of economic development matters for democracy. Lipset (1959) regarded industrialization as simply one part of a broader modernization process, including other variables such as income and education, which in turn collectively cause democracy (e.g., p. 80). Lipset (1959) did therefore never develop a theory of how industrialization affects democracy in particular, and if anything, Lipset's (1959) idea was that if any of the factors of income, education, urbanization, and industrialization did not "move together" this would lead to negative effects on democracy (pp. 81-83). I differ from this perspective by showing that it is industrialization that tends to induce democracy, and that many of the other structural factors highlighted by modernization theory do, first, not tend to develop at the same point in time as industrialization does, and, second, do not tend to have much effect on democracy after accounting for industrialization.

Second, my theory differs in terms of the causal mechanism that links economic development with democracy. For Lipset (1959) economic development leads to democracy through four causal mechanisms (pp. 83-85). First, economic development increases a population' standard of living and literacy, which in turn allows for the development of norms of tolerance, compromise, and gradualism, norms which Lipset (1959) assumes are necessary for democracy. Second, economic development tends to reduce the gap between the rich and the poor, which leads to an upper class that sees the lower class as more worthy of equal political rights. Third, a higher level of income increases a population' tolerance of democracy as it does not make too much difference if some redistribution does take place. Last, greater wealth increases the size and strength of civil society, which can function as a source of countervailing power, and acts as a training ground for new political ideas/leaders. My theory differs from Lipset (1959) by explaining which agent (manufacturing workers) tends 
to push for democracy and why this agent has both the incentive and the organizational capability to do so. Lipset (1959) does not provide a microfounded theory of democracy. If anything, it is the middle class that Lipset (1959) sees as the primary promoter of democracy. However, Lipset (1959) does not explain why the middle class would have the organizational capacity to push for democracy, and he does not explain why the middle class would have an interest in democracy, as opposed to a regime that benefits them to the exclusion of others.

\section{A.4 Lizzeri and Persico (2004)}

Lizzeri and Persico (2004) provide a formal model that is closely related to that of Llavador and Oxoby (2005). In Lizzeri and Persico s (2004) model elites that benefit from public goods have an incentive to extend the franchise because increasing the number of voters reduces the fraction of the electorate that can be wooed with ad hominem promises and therefore, by comparison, increases the electoral value of policies with diffuse benefits. My theory differ in two important respects from Lizzeri and Persico (2004).

First, Lizzeri and Persico (2004, pp. 713-714) argue that it was urbanization, not manufacturing employment, that increased the value of public goods in $19^{\text {th }}$ century Britain, which in turn lead to democratization. I show that urbanization is actually relatively weakly correlated with democracy after accounting for industrialization, and that all currently highly developed countries in the West and East Asia democratized on levels of urbanization that are low even by the standard of many of today's autocratic developing countries.

Second, my theory assumes that in rapidly industrializing countries democracy is rarely granted by elites without any pressure from below $]^{3}$ This is because while some economic elites may have an interest in better public goods provision this interest is generally triumphed by the greater risk of redistribution and more pro-labor socio-economic policies

\footnotetext{
${ }^{3}$ This is not too deny the possibility that in other cases (particularly in little industrialized countries during the Third Wave) elites may have sometimes seen it in their own economic interest to support democratization without any pressure from below. This was primarily the case because autocrats in those latter cases were less reliable partners of economic elites than government in all currently highly developed countries before democratization (Albertus and Gay, 2017).
} 
under democracy (Rueschemeyer, Stephens and Stephens, 1992). This assumption is in line with a large literature on the history of democratization in all countries that ever reached high levels of industrialization (e.g., Collier (1999), Kim (2006), Przeworski (2009), and Rueschemeyer, Stephens and Stephens (1992)). Furthermore, the results in Section 5.6 of the main text also strongly suggest that mass revolts by industrial workers mediate a significant part of the effect of industrialization on democracy.

To be sure, however, I do not exclude that some of the top-down mechanisms that Lizzeri and Persico (2004) and Llavador and Oxoby (2005) highlight may also sometimes contribute to democratization. I see my theory as a complement to, not as a substitute of, Lizzeri and Persicoss (2004) and Llavador and Oxoby]s (2005) seminal models.

\section{B Social tables of the United Kingdom in 1928}

In their seminal book Ansell and Samuels (2014) argue that the organized working class, like the urban middle class, is typically located above the economic median voter position at the time of democratization. They argue that an economic pivotal voter logic can therefore not explain why this group would have an incentive to push for free and fair elections with universal suffrage. They primarily come to this conclusion based on social tables from the United Kingdom in the year 1867.

I do not dispute Ansell and Samuels' (2014) findings with regard to Britain's social structure in 1867. Importantly, however, the Reform Act of 1867 enfranchised only about $15 \%$ of the adult population. Here I show that in 1928, when the United Kingdom introduced universal suffrage and arguably became a "full" democracy, the economic median voter was

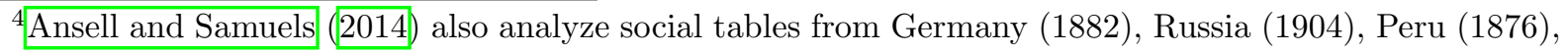
Chile (1861), and Java (1924). Russia, Peru, Chile, and Java were, however, hardly industrialzed at these times, so we would not expect manufacturing workers to be the median voter in these cases. German industrialization only really took off after the 1871 unification but even then Ansell and Samuels's (2014) own data suggests that shy of $2.7 \%$ the median voter in Germany (1882) was a textile manufacturing worker. So this case is arguably broadly in line with my hypothesis that the median voter in highly industrialized countries tends to be a manufacturing worker. As granted in footnote 29 of the main text pre-WWII Germany is a rare outlier with regard to the effect of industrialization on democracy, but this is an unrelated issue.
} 
almost certainly a relatively high-skilled and plausibly well-organized manufacturing worker.

The British Census of 1921, which is the closest Census to the year 1928, suggests that the British income distribution at the time was as follows:5

1. Higher professionals: $1.46 \%$ of the workforce, earning on average $£ 582$.

2. Employers, proprietors, managers, and administrators: $10.52 \%$ of the workforce, earning on average $£ 480$.

3. Lower professionals: $3.61 \%$ of the workforce, earning on average $£ 320$.

4. Foremen, inspectors, and supervisors: $2.61 \%$ of the workforce, earning on average $£ 268$.

5. Clerical workers: $9.52 \%$ of the workforce, earning on average $£ 182$.

6. Skilled manual workers: $25.11 \%$ of the workforce, earning on average $£ 180$.

7. Unskilled manual workers: $10.46 \%$ of the workforce, earning on average $£ 128$

8. Semi-skilled manual workers: $36.72 \%$ of the workforce, earning on average $£ 126$. (Routh, 1980, pp. 40, 120).

The median economic voter in 1921 Britain was thus a skilled manual worker. The categories for counting employees and wages within the group of skilled manual workers unfortunately do not overlap in the 1921 census, which makes it impossible to establish with certainty which group of skilled manual workers exactly held the economic median voter position at this time. We nonetheless do know that $69.1 \%$ of skilled manual workers were manufacturing workers, and that within the group of skilled manual workers approximately $11.0 \%$ and $4.4 \%$ were coalface workers and railway employees which tended to earn more on average than manufacturing workers (Routh, 1980, pp. 29, 101) [6 Taken together, this makes it very likely that manufacturing workers occupied the median economic voter position in Britain during the 1920s.

\footnotetext{
${ }^{5}$ The wages refer to males only. Employment shares include both males and females.

${ }^{6}$ Coalface workers earned more because of a risk premium. Railway employees earned more because driving trains was generally more high-skilled labor.
} 


\section{Theoretical motivation behind control variables}

In the paper I control for a large number of time-varying variables that could potentially affect both industrialization and democracy, and thus confound my two-way fixed effects estimates. Here I discuss the theoretical motivation behind the controls that I include.

Oil rents (\% of GDP): Oil rents are a strong determinant of democracy (Tsui, 2011, Ross, 2001, 2012; Andersen and Ross, 2014, Ramsay, 2011; Ahmadov, 2014) : This is most probably because the production of oil allows states to receive income without relying on taxation (which may reduce demands for accountability), because oil revenues may provide autocratic governments with additional funds for repression, and/or because oil rents may reduce the incentive to invest in education and occupational specialization (Ross, 2001, 2012). Oil could also lower the incentive to industrialize (because oil extraction generates "easy" money) and/or the capacity to industrialize (because the price of manufacturing exports increases as a result of the "Dutch Disease") (van Wijnbergen, 1984a b)

No. of past transitions: The number of past (unsustained) transitions to democracy is one of the few variables that passes the extreme bounds test of Gassebner, Lamla and Vreeland (2013). It is unclear whether this is because past experience with democracy causes democracy, or whether this variable is capturing the effect of other factors that caused transitions in the past, have lasted, and cause democracy in the present as well. The result of Gassebner, Lamla and Vreeland (2013) does suggest however that the number of past transitions is a very robust correlate of democracy. The number of past transitions may also affect industrialization, for example, because more frequent shifts in regime type may negatively affect investment confidence (Alesina et al., 1996; Alesina and Perotti, 1996).

Economic crisis: Economic recessions is also one of the few variables that passes Gassebner, Lamla and Vreeland s (2013) extreme bounds test - economic crises are a strong predictor of dictatorships breaking down 8 Although the causal mechanisms behind this

\footnotetext{
${ }^{7}$ Nonetheless the "political resource curse" is certainly not uncontroversial (e.g., Haber and Menaldo (2011)).

${ }^{8}$ There is also evidence that suggests that economic recessions tend to make it more likely that democ-
} 
correlation are somewhat elusive this may be because the legitimacy of dictatorships tends to rest particularly heavily on economic performance (as the regime type itself has little inherent legitimacy) (Guriev and Treisman, 2019; Magaloni, 2006), and/or because economic recessions create a window of opportunity to mobilize based on economic grievances (Acemoglu and Robinson, 2001; Haggard and Kaufman, 1995). Economic crises also negatively affect the manufacturing sector particularly strongly. This is because unlike in many other sectors producers can postpone selling and consumers can postpone buying so that manufacturing output contracts particularly strongly during a recession, and because manufacturing is particularly capital-intensive and capital investments tend to rebounce with a significant time lag after a recession (Eggers and Ioannides, 2006).

Duration regime: The probability of a regime change (in either democratic or authoritarian direction) declines strongly with the time that the current regime type is in place (Svolik, 2008). This is likely because political-economic actors make costly investments surrounding a particular regime type (Acemoglu and Robinson, 2006) and/or because once a regime type has been in place for a long time it may give the appearance that it is difficult to change (Little, 2017). Regime duration may also affect industrialization as political stability is a strong predictor of capital investment (Alesina et al., 1996; Alesina and Perotti, 1996).

Property rights security: New Institutional Economics suggests that private property rights security tends to cause economic development Acemoglu, Johnson and Robinson, 2001, 2005; North, 1990; Rodrik, Subramanian and Trebbi, 2004) 99 Private property right security could plausibly affect economic development through two key mechanisms. First, illdefined and poorly protected private property rights might lower investment because of the higher uncertainty for potential investors as to whether they will be able to reap the benefits of their investment in the future. Second, insecure private property rights might divert resources from productive purposes toward private protection which is likely to be inefficient due to a decrease in the division of labor and due to economies of scale in securing property racies reverse back to autocracy (Svolik, 2008).

${ }^{9}$ Nonetheless this theory is certainly not uncontroversial (e.g., Chang (2002, 2011), and Khan (2012). 
(Besley and Ghatak, 2009). The effect of private property rights security on democracy is more speculative, and New Institutional Economics in fact generally assumes that democracy causes private property rights security, rather than vice versa (e.g., Acemoglu, Johnson and Robinson (2005)). It could nonetheless be the case that private property rights security (also) affects democracy by reducing civil society' economic dependence on the state and/or by generating a more equal distribution of power in society by enabling the accumulation of wealth among groups that would otherwise be too weak to enforce their own property rights (Hayek, 1944).

Trade (\% of GDP): López-Córdova and Meissner (2008) find that greater international trade tends to induce democracy 10 They argue that this effect occurs because trade openness tends to strengthen the economic fortunes of the middle class, which in turn tends to push for democracy. International trade openness has also figured prominently on debates surrounding industrialization. Standard economic theory suggests that openness to international trade tends to foster industrialization. Proponents of the infant industry protection argument, however, suggest that while openness to exports are essential, developing countries may be better of by temporarily protecting their domestic manufacturing industries from imports coming from more technologically-advanced economies (see Lin and Chang (2009) for an excellent discussion of these opposing views).

Authoritarian constitution: Albertus and Menaldo (2018) have shown that autocratic elites often manage to remain disproportionally powerful after a transition to democracy. One of the primary channels through which autocratic elites manage to do so is by influencing, or entirely writing, the constitution of a new democracy. If the elites of the previous autocratic regime manage to influence a democracy' constitution they typically embed antimajoritarian institutions that structurally benefit their political-economic interests vis-à-vis the rest of society. Such "authoritarian" constitutions also typically contain rules that make it very difficult to lawfully change the constitution going forward. This in turn has large

\footnotetext{
${ }^{10}$ In line with this argument Aidt and Gassebner (2010) find that autocratic states trade less.
} 
negative effects on the quality of democracy. Authoritarian constitutions are also likely to negatively affect industrialization. This is because successful industrialization typically requires inclusive economic institutions that reward anyone that manages to push the economy forward, while autocratic elites tend to prefer extractive institutions that redistribute wealth from the rest of the society to them, regardless of their own actual economic contribution (Acemoglu and Robinson, 2012).

State control of economy: Research by Bellin (2000) and Rosenfeld (2017, 2021), among others, suggests that democratization becomes less likely if the state directly controls large parts of the economy. This is because such control allows autocratic elites to use the employment dependency on the state of large parts of the population to stifle democratic opposition. Standard economic theory meanwhile suggests that allocating large parts of the economy through the government, rather than the market, is generally an inefficient way to industrialize (Mankiw and Taylor, 2011) 11

Political corruption: While democracy is often seen as a potential cause of corruption (e.g., Fukuyama (2014), Rock (2009)), the relationship may also partly work the other way around. Politicians may, for example, reduce the pressure for democratization by using the public purse to selectively enrich their own supporters (De Mesquita et al., 2003). Corruption also appears to negatively affect economic development (Aidt, 2009; Mauro, 1995), although it could also be the case that corruption tends to decline because of economic development, rather than vice versa (Chang, 2002; Khan, 2012).

Aligned to West: Levitsky and Way (2005, 2010) have shown that social, economic, and technocratic ties to the West have had a large positive impact on democratization, particularly in the period after the Cold War. This is so, they argue, because such ties increase the cost of cracking down on democratic opposition for autocratic regimes. Ties with the West have also, at least in some cases, been important for industrialization. Amsden

\footnotetext{
${ }^{11}$ The relationship between state ownership and industrialization is nonetheless hardly obvious empirically. Indeed, most countries have industrialized with large parts of the manufacturing sector directly owned or otherwise strongly directed by the state. This is particularly true among the late-developers in East Asia (Amsden, 1989: Wade, 1990), but is also true in many of the early Western industrializers (Chang, 2002).
} 
(1989) and Wade (1990), for example, argue that the large scale capital and technology transfers from the United States to South Korea and Taiwan, during the Cold War, played an important role in South Korea's and Taiwan's industrialization. In the post-Cold War period one could think of similar cases. The industrialization of many East-European countries was, for example, arguably helped by market access to and capital/technology transfers from more economically advanced West-European economies after the 2004 Eastern enlargement of the European Union.

Intra-state warfare: Civil wars are by definition violent breakdowns of political order and are therefore typically highly detrimental to democracy - which in the end is a political system designed to solve communal distributional issues through free and fair elections and an independent judiciary, as opposed to through violence. Wars of all kind are also naturally very economically disruptive, hence typically negatively affecting industrialization prospects.

Inter-state warfare: International wars can clearly be fought while well-functioning democratic institutions remain in place domestically. In practice, however, international wars tend to come together with significant increases in state executive power, if not rule by decree, which does often tend to negatively affect democracy. Like civil wars inter-state warfare typically negative affects industrialization prospects. This is particularly the case if the war leads to the destruction of large amounts of (human and physical) capital and/or the interruption of important production chains. Inter-state warfare can, however, also lead to increases in industrialization. This is particularly the case when the war is mostly fought abroad and domestic industry benefits of increased demand for manufactured goods, such as weaponry (e.g., the United States during both WWI and WWII) (Block, 1977). 


\section{Measurement of control variables}

Below I discuss the measurement and data sources used for each of the control variables included in the main text.

V-dem equality index: The equal distribution of resources index of the Varieties of Democracy (V-dem) project. Higher values mean more equality. The index is based on expert survey data regarding the equality of access to health care, education, and other public goods. See Coppedge et al. (2021, p. 56) for more information.

Gini inequality: Gini coefficient of income inequality. Higher values mean more income inequality. Data comes from Bourguignon and Morrisson (2002), Babones and AlvarezRivadulla (2007), Solt (2020), and the World Bank Development Indicators.

GDP per capita: Natural log of income per capita (PPP based). Data comes from Bolt et al. (2018).

Years of education: Average years of formal education per capita. Data comes from Lee and Lee (2016).

Urbanization rate: The percentage of the population living in urban areas (as defined by the country itself). Data comes from Vanhanen (2003), Coppedge et al. (2021), and the World Bank Development Indicators.

Oil rents (\% of GDP): Petroleum production relative to total GDP. Data for both the value of petroleum production and total GDP comes from Haber and Menaldo (2011).

No. of past transitions: Number of past unsustained democratic transitions. Data comes from Boix, Miller and Rosato (2013). Democracy is defined minimally as: (1) political leaders are chosen through free and fair elections; and (2) at least $50 \%$ of the male population has the right to vote.

Economic crisis: Dummy that takes the value 1 if the GDP per capita (PPP based) growth rate relative to the previous year is negative, and 0 otherwise. Data comes from Bolt et al. (2018).

Duration regime: Number of consecutive years that the current regime type is in 
place. Regime type is defined minimally as democracy, or not. Democracy is defined as: (1) political leaders are chosen through free and fair elections; and (2) at least 50\% of the male population has the right to vote. Data comes from Boix, Miller and Rosato (2013).

Property rights security: Private property rights security index of V-dem. Variable is measured via expert surveys. Higher values mean more secure private property rights. Private property rights are defined as the right to acquire, possess, inherit, and sell private property, including land. Limits on private property rights may come from the state which may legally limit rights or fail to enforce them; customary laws and practices; or religious or social norms. This variable concerns the right to private property, not actual ownership of property. See Coppedge et al. (2021, p. 300) for more information.

Trade (\% of GDP): Imports plus exports as a percentage of total GDP. Import and export data comes from Barbieri and Keshk (2016). GDP data comes from Bolt et al. (2018).

Authoritarian constitution: Dummy that takes the value 1 if a democracy has a constitution that was written by an outgoing autocratic elite, and 0 otherwise. Data comes from Albertus and Menaldo (2018).

State control of economy: The state ownership of the economy variable of V-dem. Expert survey question that gauges the degree to which the state owns and controls capital (including land) in the industrial, agricultural, and service sectors. Higher values mean less state control. See Coppedge et al. (2021, p. 161-162) for more information.

Political corruption: The political corruption index of V-dem. Expert survey measure of the pervasiveness of corruption in the executive, legislative, and judicial branches of government. See Coppedge et al. (2021, p. 227) for more information.

Aligned to West: Dummy that takes the value 1 if a country-year is aligned to the West, and 0 otherwise. This variable always takes the value 0 before 1945 . From 1945 to 1990 Western alignment is defined as official alignment with the Western Bloc. This includes: Canada, United States, Suriname, French Guiana, Iceland, Norway, United Kingdom, Denmark, Netherlands, West Germany, Belgium, Luxembourg, France, Portugal, Spain, Italy, 
Greece, Turkey, Western Sahara, Angola, Namibia, South Africa, Zimbabwe, Mozambique, Iran, Oman, United Arab Emirates, Thailand, Philippines, South Korea, Taiwan, Japan, Papua New Guinea, Australia, and New Zealand [2] After 1990 Western alignment is defined as NATO membership, being a member state or candidate member state of the European Union, being a member state of the Schengen Agreement, being a member state of the European Economic Area, or being South Korea, Taiwan, or Japan.

Intra-state warfare: Dummy that takes the value 1 if a country was engaged in an intra-state war during any time within the past year, and 0 otherwise. Date comes from Clio Infra (clio-infra.eu), drawing on Brecke (2001).

Inter-state warfare: Dummy that takes the value 1 if a country was engaged in an inter-state war during any time within the past year, and 0 otherwise. Date comes from Clio Infra (clio-infra.eu), drawing on Brecke (2001).

\footnotetext{
${ }^{12}$ The results remain the same when also coding Pakistan as aligned (which was never officially the case).
} 


\section{E Country-years included in sample}

Table A1: Country-years included in baseline sample $(\mathrm{N}=145)$.

\begin{tabular}{|c|c|c|c|c|c|}
\hline Country & Years & Country & Years & Country & Years \\
\hline Afghanistan & $1973-2000$ & Greece & $1951-2008$ & Papua New Guinea & $1975-2001$ \\
\hline Albania & 1988-2015 & Guatemala & 1950-2006 & Paraguay & 1950-2008 \\
\hline Algeria & $1962-2004$ & Guyana & 1966-2002 & Peru & 1940-2008 \\
\hline Angola & $1975-2014$ & Haiti & $1950-1991$ & Philippines & $1948-2008$ \\
\hline Argentina & $1950-2011$ & Honduras & $1950-2007$ & Poland & 1918-2008 \\
\hline Armenia & 1991-2014 & Hungary & $1869-2008$ & Portugal & $1940-2008$ \\
\hline Australia & $1931-2008$ & India & 1950-1991 & Qatar & 1986-2014 \\
\hline Austria & 1919-2008 & Indonesia & 1961-2012 & Romania & 1930-2008 \\
\hline Azerbaijan & 1991-2014 & Iran & 1963-2015 & Russia & 1897-2008 \\
\hline Bahrain & $1992-2005$ & Iraq & $1957-2002$ & Rwanda & $1978-1989$ \\
\hline Bangladesh & $1972-2003$ & Ireland & $1936-2008$ & Saudi Arabia & $1976-2014$ \\
\hline Belarus & $2005-2015$ & Israel & $1963-2015$ & Senegal & $1974-2014$ \\
\hline Belgium & $1846-2008$ & Italy & $1881-2008$ & Sierra Leone & 1963-2004 \\
\hline Benin & $1975-1981$ & Ivory Coast & 1966-1997 & Singapore & $1965-2015$ \\
\hline Bolivia & $1950-2010$ & Jamaica & 1959-2008 & Slovakia & 1993-2015 \\
\hline Botswana & 1966-2010 & Japan & $1872-2008$ & Slovenia & 1991-2014 \\
\hline Brazil & $1950-2011$ & Jordan & 1963-2015 & Somalia & 1967-1986 \\
\hline Bulgaria & $1963-2015$ & Kazakhstan & 1998-2014 & South Africa & 1946-2008 \\
\hline Burkina Faso & $1974-1998$ & Kenya & $1963-2015$ & South Korea & 1963-2015 \\
\hline Burundi & 1969-2013 & Kuwait & 1967-2014 & Spain & $1940-2008$ \\
\hline Cambodia & $1988-2000$ & Kyrgyzstan & 1991-2014 & Sri Lanka & 1953-2008 \\
\hline Cameroon & $1970-2008$ & Laos & 1975-1999 & Sudan & 1972-2001 \\
\hline Canada & $1891-2008$ & Latvia & 1991-2015 & Suriname & 1975-2004 \\
\hline Central African Republic & 1973-1993 & Lesotho & 1982-2009 & Swaziland & $1968-2011$ \\
\hline Chile & $1940-2008$ & Liberia & $1962-1984$ & Sweden & $1945-2008$ \\
\hline China & $1952-2011$ & Libya & 1964-1996 & Switzerland & $1941-1980$ \\
\hline Colombia & 1938-2004 & Lithuania & $1992-2015$ & Syria & $1963-2010$ \\
\hline Costa Rica & $1950-2011$ & Luxembourg & 1985-2014 & Taiwan & 1949-2000 \\
\hline Croatia & 1991-2015 & Macedonia & 1991-2011 & Tajikistan & 1991-2013 \\
\hline Cuba & 1943-2008 & Madagascar & 1967-2006 & Tanzania & $1961-2011$ \\
\hline Cyrus & 1960-2008 & Malawi & 1964-2012 & Thailand & 1937-2008 \\
\hline Czech Republic & 1987-2015 & Malaysia & $1968-2015$ & The Gambia & 1975-2004 \\
\hline Democratic Republic of Congo & $1968-1988$ & Mali & 1976-2004 & Trinidad and Tobago & 1962-2008 \\
\hline Denmark & $1945-2008$ & Mauritius & $1968-2008$ & Tunisia & 1963-2014 \\
\hline Dominican Republic & $1950-2007$ & Mexico & $1930-2008$ & Turkey & 1935-2008 \\
\hline Ecuador & $1950-2006$ & Moldova & 1991-2014 & Uganda & $1963-2000$ \\
\hline Egypt & $1937-2008$ & Mongolia & 1990-2014 & Ukraine & 1992-2015 \\
\hline El Salvador & $1950-2007$ & Morocco & 1960-2012 & United Arab Emirates & $1971-2010$ \\
\hline Eritrea & 1993-2011 & Mozambique & $1975-2000$ & United Kingdom & $1841-2008$ \\
\hline Estonia & 1993-2015 & Myanmar & 1983-1997 & United States of America & $1870-2008$ \\
\hline Ethiopia & 1961-1993 & Nepal & 1961-1999 & Uruguay & $1968-2012$ \\
\hline Fiji & 1970-2013 & Netherlands & 1849-2008 & Venezuela & $1941-2008$ \\
\hline Finland & 1917-2008 & New Zealand & 1906-2008 & Yemen & 1988-2013 \\
\hline France & $1856-2008$ & Nicaragua & 1940-2006 & Zambia & $1965-2010$ \\
\hline Gabon & 1963-1995 & Niger & 1960-1977 & Zimbabwe & 1970-1996 \\
\hline Georgia & 1998-2015 & Nigeria & 1960-2011 & & \\
\hline Germany (Post-1990) & 1991-2015 & Norway & 1930-2008 & & \\
\hline Germany (Pre-1945) & 1882-1939 & Oman & $1993-2015$ & & \\
\hline West Germany (1945-1990) & $1950-1990$ & Pakistan & $1972-2008$ & & \\
\hline Ghana & 1960-2011 & Panama & $1940-2008$ & & \\
\hline
\end{tabular}




\section{F Descriptive statistics}

Table A2: Summary statistics.

\begin{tabular}{|c|c|c|c|c|c|c|}
\hline Variable & $\mathrm{N}$ & Mean & $\begin{array}{l}\text { Overall } \\
\text { Std. Dev. }\end{array}$ & $\begin{array}{l}\text { Within } \\
\text { Std. Dev. }\end{array}$ & Min & $\operatorname{Max}$ \\
\hline V-dem liberal democracy index & 1,318 & 3.780 & 2.800 & 1.416 & 0.142 & 8.901 \\
\hline V-dem electoral democracy index & 1,320 & 6.325 & 2.772 & 1.577 & 0.297 & 9.725 \\
\hline Combined Polity IV index & 1,248 & 6.217 & 3.664 & 1.997 & 0 & 10 \\
\hline Lexical electoral democracy index & 1,281 & 3.859 & 2.332 & 1.468 & 0 & 6 \\
\hline Boix et.al. (2013) democracy & 1,275 & 0.536 & 0.499 & 0.300 & 0 & 1 \\
\hline Cheibub et.al. (2010) democracy & 1,072 & 0.517 & 0.500 & 0.279 & 0 & 1 \\
\hline Universal suffrage & 1,292 & 0.760 & 0.427 & 0.337 & 0 & 1 \\
\hline Male suffrage & 1,292 & 0.802 & 0.399 & 0.307 & 0 & 1 \\
\hline$\%$ in manufacturing & 1,367 & 5.320 & 4.023 & 1.518 & 0.016 & 19.041 \\
\hline Gini income inequality & 1,030 & 37.652 & 9.644 & 3.271 & 17.964 & 66.957 \\
\hline V-dem equality index & 1,292 & 0.589 & 0.285 & 0.114 & 0.034 & 0.986 \\
\hline Average years of education & 1,073 & 5.957 & 3.094 & 1.944 & 0.359 & 13.105 \\
\hline Natural log of GDP per capita & 1,200 & 8.695 & 1.074 & 0.531 & 5.922 & 11.720 \\
\hline Urbanization rate & 1,299 & 43.826 & 24.632 & 13.669 & 1.600 & 100 \\
\hline Oil rents ( $\%$ of GDP) & 1,126 & 3.644 & 11.200 & 6.081 & 0 & 128.066 \\
\hline No. of past transitions & 1,256 & 0.391 & 0.738 & 0.318 & 0 & 4 \\
\hline Economic crisis & 1,200 & 0.274 & 0.446 & 0.415 & 0 & 1 \\
\hline Duration regime & 1,275 & 45.655 & 49.078 & 24.009 & 1 & 216 \\
\hline Property rights security & 1,321 & 6.397 & 2.485 & 1.057 & 0.032 & 9.525 \\
\hline Trade (\% of GDP) & 1,094 & 2.181 & 8.421 & 5.570 & 0.008 & 172.893 \\
\hline Authoritarian constitution & 1,150 & 0.118 & 0.323 & 0.229 & 0 & 1 \\
\hline State control of economy & 1,321 & 0.332 & 1.198 & 0.673 & -4.018 & 2.657 \\
\hline Political corruption & 1,311 & 0.434 & 0.301 & 0.092 & 0.006 & 0.969 \\
\hline Aligned to West & 1,367 & 0.249 & 0.433 & 0.258 & 0 & 1 \\
\hline Inter-state warfare & 1,367 & 0.072 & 0.258 & 0.210 & 0 & 1 \\
\hline Intra-state warfare & 1,367 & 0.092 & 0.289 & 0.226 & 0 & 1 \\
\hline
\end{tabular}

Note: Data is observed in years ending with 0 and 5's (i.e., 5 year regular intervals). Sample is subsetted to country-years when $\%$ in manufacturing is non-missing. 


\section{G Accounting for mature deindustrialization}

In the main text I test the effect of industrialization on democracy using a linear dynamic panel model with country and time fixed effects. This has two advantages. First, such models are easy to interpret. Second, this specification follows the precedent set by the current stateof-the-art econometric literature on the economic roots of democracy (e.g., Acemoglu et al. (2008), Boix (2011), and Treisman (2015)).

In the context of my theory linear dynamic panel models with country and time fixed effects are, however, likely to underestimate the effect of industrialization on democracy. This is because my theory suggests that the higher labor productivity in manufacturing tends to generate a structural change in employment from manufacturing to modern services in highly industrialized countries which, importantly, still supports democracy (see Section 2.3 in the main text).

In Table A3 I take this into account by interacting my key $\%$ in manufacturing variable with a dummy that takes the value 1 if the country-year is a highly industrialized country in the post-1945 period and if this country-year has seen a decline in its level of manufacturing employment in the previous 5 years, and 0 otherwise 13

As can be seen in Table A3 mature deindustrialization has a positive (but statistically insignificant) effect on democracy. This is in line with my theory that the shift towards modern service employment after widespread industrialization still supports democracy. The implied long-run effect of industrialization on democracy is estimated to be 0.673 within the null category of the mature deindustrialization dummy, which are country-years without mature deindustrialization. In line with the logic outlined above this is marginally larger than the baseline estimate of 0.661 , which is obtained when simply pooling mature deindustrialization together with all other forms of (de)industrialization.

\footnotetext{
${ }^{13}$ Highly industrialized countries are coded as: Canada, United States, Norway, Sweden, Finland, Denmark, Ireland, United Kingdom, Netherlands, Germany, Belgium, Luxembourg, Austria, France, Switzerland, Portugal, Spain, Italy, Greece, Australia, New Zealand, Japan, South Korea, Taiwan, Singapore, and Hong Kong. Results are robust to using the OECD as the group identifier.
} 
Table A3: Accounting for mature deindustrialization.

\begin{tabular}{|c|c|c|c|c|c|c|}
\hline & $(1)$ & $(2)$ & $(3)$ & $(4)$ & $(5)$ & (6) \\
\hline Democracy $_{t-1}$ & $\begin{array}{c}0.583^{* * *} \\
(0.039)\end{array}$ & $\begin{array}{c}0.562^{* * *} \\
(0.045)\end{array}$ & $\begin{array}{c}0.597^{* * *} \\
(0.045)\end{array}$ & $\begin{array}{c}0.533^{* * *} \\
(0.049)\end{array}$ & $\begin{array}{c}0.544^{* * *} \\
(0.043)\end{array}$ & $\begin{array}{c}0.581^{* * *} \\
(0.040)\end{array}$ \\
\hline$\%$ in manufacturing $t-1$ & $\begin{array}{l}0.280^{*} \\
(0.112)\end{array}$ & $\begin{array}{c}0.487^{* *} \\
(0.162)\end{array}$ & $\begin{array}{c}0.341^{* *} \\
(0.130)\end{array}$ & $\begin{array}{l}0.250^{+} \\
(0.138)\end{array}$ & $\begin{array}{l}0.241^{*} \\
(0.122)\end{array}$ & $\begin{array}{l}0.278^{*} \\
(0.118)\end{array}$ \\
\hline Mature deindustrialization ${ }_{t-1}$ & $\begin{array}{c}0.063 \\
(0.247)\end{array}$ & $\begin{array}{c}0.153 \\
(0.279)\end{array}$ & $\begin{array}{c}0.200 \\
(0.277)\end{array}$ & $\begin{array}{c}0.045 \\
(0.258)\end{array}$ & $\begin{array}{l}-0.033 \\
(0.247)\end{array}$ & $\begin{array}{c}0.055 \\
(0.247)\end{array}$ \\
\hline $\begin{array}{l}\% \text { in manufacturing } t-1 \\
\text { Mature deindustrialization }{ }_{t-1}\end{array}$ & $\begin{array}{c}0.064 \\
(0.142)\end{array}$ & $\begin{array}{c}0.055 \\
(0.178)\end{array}$ & $\begin{array}{c}0.025 \\
(0.160)\end{array}$ & $\begin{array}{c}0.059 \\
(0.124)\end{array}$ & $\begin{array}{c}0.134 \\
(0.151)\end{array}$ & $\begin{array}{c}0.061 \\
(0.144)\end{array}$ \\
\hline GINI income inequality ${ }_{t-1}$ & & $\begin{array}{c}0.272 \\
(0.167)\end{array}$ & & & & \\
\hline Log GDP per capita $t-1$ & & $\begin{array}{l}-0.450^{*} \\
(0.206)\end{array}$ & & & & \\
\hline Years of education $t-1$ & & $\begin{array}{c}0.325 \\
(0.304)\end{array}$ & & & & \\
\hline Urbanization rate $_{t-1}$ & & $\begin{array}{l}0.336^{+} \\
(0.187)\end{array}$ & & & & \\
\hline Oil rents (\% of GDP) ${ }_{t-1}$ & & & $\begin{array}{l}-0.011 \\
(0.063)\end{array}$ & & & \\
\hline No. of past transitions $t-1$ & & & $\begin{array}{c}0.299^{* * *} \\
(0.072)\end{array}$ & & & \\
\hline Economic crisis $_{t-1}$ & & & $\begin{array}{l}-0.004 \\
(0.073)\end{array}$ & & & \\
\hline Duration regime $_{t-1}$ & & & & $\begin{array}{c}-0.196^{* *} \\
(0.071)\end{array}$ & & \\
\hline Property rights security $t-1$ & & & & $\begin{array}{c}0.077 \\
(0.059)\end{array}$ & & \\
\hline Trade $(\% \text { of GDP })_{t-1}$ & & & & $\begin{array}{l}-0.038 \\
(0.032)\end{array}$ & & \\
\hline Authoritarian constitution $_{t-1}$ & & & & & $\begin{array}{c}0.143 \\
(0.196)\end{array}$ & \\
\hline State control of economy ${ }_{t-1}$ & & & & & $\begin{array}{c}0.132 \\
(0.095)\end{array}$ & \\
\hline Political corruption $t-1$ & & & & & $\begin{array}{c}-0.412^{* * *} \\
(0.112)\end{array}$ & \\
\hline Aligned to West ${ }_{t-1}$ & & & & & & $\begin{array}{l}-0.131 \\
(0.125)\end{array}$ \\
\hline Inter-state warfare ${ }_{t-1}$ & & & & & & $\begin{array}{l}-0.250^{*} \\
(0.121)\end{array}$ \\
\hline Intra-state warfare $t-1$ & & & & & & $\begin{array}{l}-0.046 \\
(0.149)\end{array}$ \\
\hline $\begin{array}{l}\text { Implied long-run effect of } \\
\% \text { in manufacturing } t-1\end{array}$ & $\begin{array}{l}0.673^{*} \\
(0.286)\end{array}$ & $\begin{array}{l}1.113^{* *} \\
(0.402)\end{array}$ & $\begin{array}{l}0.847^{*} \\
(0.346)\end{array}$ & $\begin{array}{l}0.537^{+} \\
(0.313)\end{array}$ & $\begin{array}{l}0.527^{+} \\
(0.278)\end{array}$ & $\begin{array}{l}0.663^{*} \\
(0.299)\end{array}$ \\
\hline Country fixed effects & Yes & Yes & Yes & Yes & Yes & Yes \\
\hline Time fixed effects & Yes & Yes & Yes & Yes & Yes & Yes \\
\hline Observations & 1292 & 773 & 1035 & 1078 & 1134 & 1292 \\
\hline Countries & 145 & 87 & 126 & 128 & 135 & 145 \\
\hline
\end{tabular}

Notes: OLS regressions. The dependent variable is the liberal democracy index of V-dem. See Appendix $\mathrm{D}$ for measurement of control variables. Data is observed in years ending with 0 and 5's (i.e., 5 year regular intervals). Robust standard errors clustered on the country level in parentheses.

$* * * \mathrm{p}<0.001, * * \mathrm{p}<0.01, * \mathrm{p}<0.05,{ }^{+} \mathrm{p}<0.10 . \quad 18$ 


\section{H Controls for mining/agricultural employment and manufacturing output}

My theory suggests that a shift towards a large share of employment in manufacturing tends to increase the likelihood that a country becomes a stable democracy. In line with this hypothesis I find that the percentage of the population employed in manufacturing is strongly correlated with democracy, even after accounting for country and time fixed effects and a large number of time-varying control variables.

Here I examine whether this effect is truly driven by changes in manufacturing employment, as opposed to other structural economic changes that tend to correlate with changes in manufacturing employment. To do so I use data from GGDC (2015) and Mitchell (2013) to control for the share of the population employed in agriculture and mining, and data from GGDC (2015), UNIDO (2015), and the World Bank Development Indicators on manufacturing value added.

As can be seen in Table A4 manufacturing employment remains strongly positively correlated with democracy after accounting for employment in mining and agriculture, and after accounting for manufacturing value added. Because of the fact that some of this additional data is only available for relatively few country-years the effect of industrialization generally ceases to be statistically significant on conventional levels, but all effects remains economically very large. Furthermore, mining and agricultural employment, as well as manufacturing output, are themselves negatively associated with democracy after accounting for manufacturing employment. This increases my confidence that it really is manufacturing employment that is driving the effect. 
Table A4: Accounting for employment in agriculture and mining, and manufacturing output.

\begin{tabular}{|c|c|c|c|c|c|}
\hline & $(1)$ & $(2)$ & $(3)$ & $(4)$ & $(5)$ \\
\hline Democracy $t-1$ & $\begin{array}{c}0.586^{* * *} \\
(0.039)\end{array}$ & $\begin{array}{c}0.620^{* * *} \\
(0.056)\end{array}$ & $\begin{array}{c}0.615^{* * *} \\
(0.043)\end{array}$ & $\begin{array}{c}0.550^{* * *} \\
(0.042)\end{array}$ & $\begin{array}{c}0.543^{* * *} \\
(0.040)\end{array}$ \\
\hline$\%$ in manufacturing $t-1$ & $\begin{array}{l}0.274^{* *} \\
(0.091)\end{array}$ & $\begin{array}{c}0.145 \\
(0.129)\end{array}$ & $\begin{array}{l}0.241^{*} \\
(0.111)\end{array}$ & $\begin{array}{c}0.184 \\
(0.131)\end{array}$ & $\begin{array}{c}0.219 \\
(0.131)\end{array}$ \\
\hline$\%$ in mining $t-1$ & & $\begin{array}{l}-0.132 \\
(0.099)\end{array}$ & & & \\
\hline$\%$ in agriculture $t-1$ & & & $\begin{array}{l}-0.099 \\
(0.207)\end{array}$ & & \\
\hline MVA per capita $t-1$ & & & & $\begin{array}{l}-0.181 \\
(0.093)\end{array}$ & \\
\hline $\operatorname{MVA}(\% \text { of GDP })_{t-1}$ & & & & & $\begin{array}{c}-0.384^{* *} \\
(0.138)\end{array}$ \\
\hline $\begin{array}{l}\text { Implied long-run effect of } \\
\% \text { in manufacturing } t-1\end{array}$ & $\begin{array}{c}0.661^{* *} \\
(0.230)\end{array}$ & $\begin{array}{c}0.381 \\
(0.354)\end{array}$ & $\begin{array}{l}0.626^{*} \\
(0.296)\end{array}$ & $\begin{array}{c}0.408 \\
(0.299)\end{array}$ & $\begin{array}{c}0.479 \\
(0.291)\end{array}$ \\
\hline Country fixed effects & Yes & Yes & Yes & Yes & Yes \\
\hline Time fixed effects & Yes & Yes & Yes & Yes & Yes \\
\hline Observations & 1292 & 539 & 973 & 921 & 922 \\
\hline Countries & 145 & 74 & 98 & 124 & 124 \\
\hline
\end{tabular}

Notes: OLS regressions. The dependent variable is the liberal democracy index of V-dem. Data is observed in years ending with 0 and 5's (i.e., 5 year regular intervals). Robust standard errors clustered on the country level in parentheses.

$* * * \mathrm{p}<0.01, * * \mathrm{p}<0.05, * \mathrm{p}<0.10$. 


\section{References}

Acemoglu, Daron and James A. Robinson. 2001. "A Theory of Political Transitions." American Economic Review 91(4):938-963.

Acemoglu, Daron and James A. Robinson. 2006. Economic Origins of Dictatorship and Democracy. Cambridge University Press.

Acemoglu, Daron and James A Robinson. 2012. Why Nations Fail: The Origins of Power, Prosperity, and Poverty. Crown Business.

Acemoglu, Daron, Simon Johnson and James A. Robinson. 2001. "The Colonial Origins of Comparative Development: An Empirical Investigation." American Economic Review 91(5):1369-1401.

Acemoglu, Daron, Simon Johnson and James A. Robinson. 2005. Institutions as a Fundamental Cause of Long-Run Growth. In Handbook of Economic Growth, ed. Philippe Aghion and Stephen Durlauf. Elsevier pp. 385-472.

Acemoglu, Daron, Simon Johnson, James A. Robinson and Pierre Yared. 2008. "Income and Democracy." American Economic Review 98(3):808-42.

Ahmadov, Anar K. 2014. "Oil, Democracy, and Context: A Meta-Analysis." Comparative Political Studies 47(9):1238-1267.

Aidt, Toke S. 2009. "Corruption, Institutions, and Economic Development." Oxford Review of Economic Policy 25(2):271-291.

Aidt, Toke S. and Martin Gassebner. 2010. "Do Autocratic States Trade Less?" World Bank Economic Review 24(1):38-76.

Albertus, Michael and Victor Gay. 2017. "Unlikely Democrats: Economic Elite Uncertainty Under Dictatorship and Support for Democratization." American Journal of Political Science 61(3):624-641.

Albertus, Michael and Victor Menaldo. 2018. Authoritarianism and the Elite Origins of Democracy. Cambridge University Press.

Alesina, Alberto and Roberto Perotti. 1996. "Income Distribution, Political Instability, and Investment." European Economic Review 40(6):1203-1228.

Alesina, Alberto, Sule Özler, Nouriel Roubini and Phillip Swagel. 1996. "Political Instability and Economic Growth." Journal of Economic Growth 1(2):189-211.

Amsden, Alice H. 1989. Asia's Next Giant: South Korea and Late Industrialization. Oxford University Press.

Andersen, Jørgen J. and Michael L. Ross. 2014. "The Big Oil Change: A Closer Look at the Haber-Menaldo Analysis." Comparative Political Studies 47(7):993-1021.

Ansell, Ben W. and David J. Samuels. 2014. Inequality and Democratization: An EliteCompetition Approach. Cambridge University Press.

Babones, Salvatore J. and María J. Alvarez-Rivadulla. 2007. "Standardized Income Inequality Data for use in Cross-National Research." Sociological Inquiry 77(1):3-22.

Barbieri, Katherine and Omar M.G. Keshk. 2016. "Correlates of War Project Trade Data Set Codebook, Version 4.0." Available at: http://correlatesof war .org (last accessed: December 2, 2021).

Bellin, Eva. 2000. "Contingent Democrats: Industrialists, Labor, and Democratization in Late-Developing Countries." World Politics 52(2):175-205.

Besley, Timothy and Maitreesh Ghatak. 2009. Property Rights and Economic Development. 
In Handbook of Development Economics, ed. Dani Rodrik and Mark Rosenzweig. Vol. 5 Amsterdam: Elsevier pp. 4526-4592.

Block, Fred L. 1977. The Origins of International Economic Disorder: A Study of United States International Monetary Policy from World War II to the Present. University of California Press.

Boix, Carles. 2003. Democracy and Redistribution. Cambridge University Press.

Boix, Carles. 2011. "Democracy, Development, and the International System." American Political Science Review 105(4):809-828.

Boix, Carles, Michael K. Miller and Sebastian Rosato. 2013. "A Complete Data Set of Political Regimes, 1800-2007." Comparative Political Studies 46(12):1523-1554.

Bolt, Jutta, Robert Inklaar, Herman de Jong and Jan Luiten van Zanden. 2018. "Rebasing 'Maddison': New Income Comparisons and the Shape of Long-Run Economic Development." Maddison Project Working Paper 10.

Bourguignon, François and Christian Morrisson. 2002. "Inequality Among World Citizens: 1820-1992." American Economic Review 92(4):727-744.

Brecke, Peter. 2001. The Long-Term Patterns of Violent Conflict in Different Regions of the World. In Uppsala Conflict Data Conference, Uppsala, Sweden.

Chang, Ha-Joon. 2002. Kicking Away the Ladder: Development Strategy in Historical Perspective. Anthem Press.

Chang, Ha-Joon. 2011. "Institutions and Economic Development: Theory, Policy and History." Journal of Institutional Economics 7(04):473-498.

Collier, Ruth B. 1999. Paths Toward Democracy: The Working Class and Elites in Western Europe and South America. Cambridge University Press.

Coppedge, Michael et al. 2021. V-Dem Codebook v11.1. Varieties of democracy (v-dem) project.

De Mesquita, Bruce B., Alastair Smith, Randolph M. Siverson and James D. Morrow. 2003. The Logic of Political Survival. MIT press.

Eggers, Andrew and Yannis M. Ioannides. 2006. "The Role of Output Composition in the Stabilization of US Output Growth." Journal of Macroeconomics 28(3):585-595.

Freeman, John R. and Dennis P. Quinn. 2012. "The Economic Origins of Democracy Reconsidered." American Political Science Review pp. 58-80.

Fukuyama, Francis. 2014. Political Order and Political Decay: From the Industrial Revolution to the Globalization of Democracy. Profile Books Ltd.

Gassebner, Martin, Michael J. Lamla and James R. Vreeland. 2013. "Extreme Bounds of Democracy." Journal of Conflict Resolution 57(2):171-197.

GGDC, The Groningen Growth and Development Centre. 2015. "The GGDC 10-Sector Database." Available at: https://www.rug.nl/ggdc/productivity/10-sector/ (last accessed: April 11, 2019).

Guriev, Sergei and Daniel Treisman. 2019. "Informational Autocrats." Journal of Economic Perspectives 33(4):100-127.

Haber, Stephen and Victor Menaldo. 2011. "Do Natural Resources Fuel Authoritarianism? A Reappraisal of the Resource Curse." American Political Science Review 105(1):1-26.

Haggard, Stephan and Robert R. Kaufman. 1995. The Political Economy of Democratic Transitions. Princeton University Press.

Hayek, Friedrich A. 1944. The Road to Serfdom. University of Chicago Press. 
Houle, Christian. 2009. "Inequality and Democracy: Why Inequality Harms Consolidation but Does Not Affect Democratization." World Politics 61:589.

Inglehart, Ronald and Christian Welzel. 2005. Modernization, Cultural Change, and Democracy: The Human Development Sequence. Cambridge University Press.

Khan, Mushtaq. 2012. Governance and Growth: History, Ideology and Methods of Proof. In Good Growth and Governance in Africa: Rethinking Development Strategies, ed. Akbar Noman, Kwesi Botchwey, Howard Stein and Joseph E. Stiglitz. Oxford University Press pp. 51-79.

Kim, Sunhyuk. 2006. Civil Society and Democratization in South Korea. In Korean Society, ed. Andrew E. Kim. Routledge pp. 65-84.

Lee, Jong-Wha and Hanol Lee. 2016. "Human Capital in the Long Run." Journal of Development Economics 122:147-169.

Levitsky, Steven and Lucan A. Way. 2005. "International Linkage and Democratization." Journal of Democracy 16(3):20-34.

Levitsky, Steven and Lucan A. Way. 2010. Competitive Authoritarianism: Hybrid Regimes after the Cold War. Cambridge University Press.

Lin, Justin and Ha-Joon Chang. 2009. "Should Industrial Policy in Developing Countries Conform to Comparative Advantage or Defy It? A Debate between Justin Lin and HaJoon Chang." Development Policy Review 27(5):483-502.

Lipset, Seymour M. 1959. "Some Social Requisites of Democracy: Economic Development and Political Legitimacy." American Political Science Review 53(1):69-105.

Little, Andrew T. 2017. "Coordination, Learning, and Coups." Journal of Conflict Resolution 61(1):204-234.

Lizzeri, Alessandro and Nicola Persico. 2004. "Why Did the Elites Extend the Suffrage? Democracy and the Scope of Government, with an Application to Britain's "Age of Reform"." Quarterly Journal of Economics 119(2):707-765.

Llavador, Humberto and Robert J. Oxoby. 2005. "Partisan Competition, Growth, and the Franchise." Quarterly Journal of Economics 120(3):1155-1189.

López-Córdova, J. Ernesto and Christopher M. Meissner. 2008. "The Impact of International Trade on Democracy: A Long-Run Perspective." World Politics 60(4):539-575.

Magaloni, Beatriz. 2006. Voting for Autocracy: Hegemonic Party Survival and its Demise in Mexico. Cambridge University Press.

Mankiw, Gregory N. and Mark P. Taylor. 2011. Economics (2nd edition). R.R. Donnelley, China.

Mauro, Paolo. 1995. "Corruption and Growth." Quarterly Journal of Economics 110(3):681712.

Mitchell, Brian. 2013. International Historical Statistics. Palgrave Macmillan.

North, Douglass C. 1990. Institutions, Institutional Change and Economic Performance. Cambridge University Press.

Przeworski, Adam. 2009. "Conquered or Granted? A History of Suffrage Extensions." British Journal of Political Science 39(2):291-321.

Ramsay, Kristopher W. 2011. "Revisiting the Resource Curse: Natural Disasters, the Price of Oil, and Democracy." International Organization 65(3):507-529.

Rock, Michael T. 2009. "Corruption and Democracy." Journal of Development Studies 45(1):55-75. 
Rodrik, Dani, Arvind Subramanian and Francesco Trebbi. 2004. "Institutions Rule: The Primacy of Institutions over Geography and Integration in Economic Development." Journal of Economic Growth 9(2):131-165.

Rosendorff, B. Peter. 2001. "Choosing Democracy." Economics $\&$ Politics 13(1):1-29.

Rosenfeld, Bryn. 2017. "Reevaluating the Middle-Class Protest Paradigm: A Case-Control Study of Democratic Protest Coalitions in Russia." American Political Science Review 111(4):637-652.

Rosenfeld, Bryn. 2021. "State Dependency and the Limits of Middle Class Support for Democracy." Comparative Political Studies 54:411-444.

Ross, Michael. 2012. The Oil Curse: How Petroleum Wealth Shapes the Development of Nations. Princeton University Press.

Ross, Michael L. 2001. "Does Oil Hinder Democracy?" World Politics 53(3):325-361.

Routh, Guy. 1980. Occupation and Pay in Great Britain 1906-79. Springer.

Rueschemeyer, Dietrich, Evelyne H. Stephens and John D. Stephens. 1992. Capitalist Development and Democracy. Cambridge University Press.

Solt, Frederick. 2020. "Measuring Income Inequality across Countries and Over Time: The Standardized World Income Inequality Database." Social Science Quarterly 101(3):11831199.

Svolik, Milan. 2008. "Authoritarian Reversals and Democratic Consolidation." American Political Science Review pp. 153-168.

Treisman, Daniel. 2015. "Income, Democracy, and Leader Turnover." American Journal of Political Science 59(4):927-942.

Tsui, Kevin K. 2011. "More Oil, Less Democracy: Evidence from Worldwide Crude Oil Discoveries." Economic Journal 121(551):89-115.

UNIDO, The United Nations Industrial Development Organization. 2015. "INDSTAT2 Industrial Statistics Database." Available at: https://www.unido.org/researchers/ statistical-databases (last accessed: April 11, 2019).

van Wijnbergen, Sweder. 1984a. "The Dutch Disease': A Disease After All?" Economic Journal 94(373):41-55.

van Wijnbergen, Sweder. 1984b. "Inflation, Employment, and the Dutch Disease in OilExporting Countries: A Short-Run Disequilibrium Analysis." Quarterly Journal of Economics 99(2):233-250.

Vanhanen, Tatu. 2003. Democratization and Power Resources, 1850-2000. Finnish Social Science Data Archive.

Wade, Robert. 1990. Governing the Market: Economic Theory and the Role of Government in East Asian Industrialization. Princeton University Press. 